\title{
Summary of HTGR Benchmark Data from the High Temperature Lattice Test Reactor
}

D. F. Newman

October 1989

Prepared for Los Alamos National Laboratory under the U.S. Department of Energy

Contract DE-AC06-76RLO 1830

Pacific Northwest Laboratory Operated for the U.S. Department of Energy by Battelle Memorial Institute

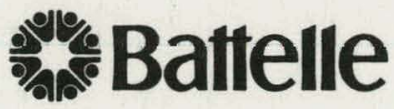




\section{DISCLAIMER}

This report was prepared as an account of work sponsored by an agency of the United States Government. Neither the United States Government nor any agency Thereof, nor any of their employees, makes any warranty, express or implied, or assumes any legal liability or responsibility for the accuracy, completeness, or usefulness of any information, apparatus, product, or process disclosed, or represents that its use would not infringe privately owned rights. Reference herein to any specific commercial product, process, or service by trade name, trademark, manufacturer, or otherwise does not necessarily constitute or imply its endorsement, recommendation, or favoring by the United States Government or any agency thereof. The views and opinions of authors expressed herein do not necessarily state or reflect those of the United States Government or any agency thereof. 


\section{DISCLAIMER}

Portions of this document may be illegible in electronic image products. Images are produced from the best available original document. 


\section{The following pages are an exact representation of what is in the original document folder.}




\title{
DISCLAIMER
}

This program was prepared as an account of work sponsored by an agency of the United States Government. Neither the United States Government nor any agency thereof, nor Battelle Memorial Institute, nor any or their employees, makes any warranty, expressed or implied, or assumes any legal liability or responsibility for the accuracy, completeness, or usefulness of any information, apparatus, product, or process disclosed, or represents that its use would not infringe privately owned rights. Reference herein to any specific commercial product, process, or service by trade name, trademark, manufacturer, or otherwise, does not necessarily constitute or imply its endorsement, recommendatıon, or tavoring by the United States Government of any agency thereof, or Battelle Memorial Institute. The views and opinions of authors expressed herein do not necessarily state or reflect those of the United States Government or any agency thereof.

\author{
PACIFIC NORTHWEST LABORATORY \\ operated by \\ BATTELLE MEMORIAL INSTITUTE \\ for the \\ UNITED STATES DEPARTMENT OF ENERGY \\ under Contract DE-AC06-76RLO 1830
}

Printed in the United States of America

Available to DOE and DOE contractors from the

Office of Scientific and Technical Information, P.O. Box 62, Oak Ridge, TN 37831 ;

prices available from (615) 576-8401. FTS 626-8401.

Available to the public from the National Technical Infurmatiun Service,

U.S. Department of Commerce, 5285 Port Royal Rd., Springfield, VA 22161.

NTIS Price Codes, Microfiche A01

\begin{tabular}{|c|c|}
\hline \multicolumn{2}{|c|}{ Printed Copy } \\
\hline Pages & $\begin{array}{l}\text { Price } \\
\text { Codes }\end{array}$ \\
\hline $001-025$ & $\mathrm{A02}$ \\
\hline 026-050 & $\mathrm{A} 03$ \\
\hline $051-075$ & A04 \\
\hline $076-100$ & A05 \\
\hline $101-125$ & $A 0 G$ \\
\hline $126-150$ & A07 \\
\hline $151-175$ & A08 \\
\hline $176-200$ & A09 \\
\hline $201-225$ & A10 \\
\hline $226-250$ & A11 \\
\hline $251-275$ & A12 \\
\hline $276-300$ & A13 \\
\hline
\end{tabular}


SUMMARY OF HTGR BENCHMARK DATA FROM THE HIGH TEMPERATURE

LATTICE TEST REACTOR

D. F. Newman

October 1989

Prepared for Los Alamos National Laboratory under U.S. Department of Energy Contract DE-AC06-76RLO 1830

Pacific Northwest Laboratory Richland, Washington 99352 


\section{THIS PAGE \\ WAS INTENTIONALLY \\ LEFT BLANK}




\section{SUMMARY}

The High Temperature Lattice Test Reactor (HTLTR) was a unique critical facility specifically built and operated to measure variations in neutronic characteristics of high temperature gas cooled reactor (HTGR) lattices at temperatures up to $1000^{\circ} \mathrm{C}$. The Los Alamos National Laboratory commissioned Pacific Northwest Laboratory (PNL) to prepare this summary reference report on the HTLTR benchmark data and its associated documentation. Extensive efforts were applied by PNL since 1965, throughout the experimental and analytic phases of the benchmark data generation, to provide validation and verification of the results. In the initial stages of the program, the principle of the measurement of $k_{\infty}$ using the unpoisoned technique (developed by $R$. E. Heineman of PNL) was subjected to extensive peer review within PNL and the General Atomic Company. A number of experiments were conducted at PNL in the Physical Constants Testing Reactor (PCTR) using both the unpoisoned technique and the well-established null reactivity technique that substantiated the equivalence of the measurements by direct comparison. The methods used and the experimental results were published in peer-reviewed journals: Nuclear Science and Engineering and Nuclear Technology as well as being presented at National meetings of the American Nuclear Society and published in Transactions of the American Nuclear Society. Records of all data from fuel fabrication, the reactor experiments, and the analytical results were compiled and maintained to meet applicable quality assurance standards in place at PNL. Sensitivity of comparisons between measured and calculated $k_{m}(T)$ data for various HTGR lattices to changes in neutron cross section data, graphite scattering kernel models, and fuel block loading variations, were analyzed by PNL for the Electric Power Research Institute. The results of this review and correlation of calculated and measured results was published in the peer-reviewed journal, Nuclear Technology. As a part of this effort, the fuel rod composition in the dilute ${ }^{233} \mathrm{UO}_{2}$-ThO 2 HTGR central ce11 (HTLTR Lattice \#3) was sampled and analyzed by mass spectrometry. Values of $k_{\infty}$ calculated for that lattice were about $5 \%$ higher than those measured. Trace quantities of sodium chloride were found in the fuel rod that were equivalent to 22 atom parts-per-million of natural boron. 
Calculations that included this impurity concentration in the fuel were in good agreement with the measured value at room temperature.

External peer reviewers of the HTLTR benchmark data and analyses

included: R. C. Dahlberg, J. R. Brown, D. R. Mathews, and K. R. Schultz (General Atomic); G. L. Ragan (ORNL); Odelli Ozer (EPRI). The measured $k_{\infty}(T)$ data, summarized in this report, provides a verifiable basis for validating temperature coefficients of reactivity for HTGR lattices, even though they predate NQA-1 requirements. 


\section{CONTENTS}

SUMMARY . . . . . . . . . . . . . . . . . . . . . . . i i i

INTRODUCTION . . . . . . . . . . . . . . . . . . . . 1

DESCRIPTION OF THE HTLTR . . . . . . . . . . . . . . . 5

HTGR BENCHMARK DATA . . . . . . . . . . . . . . . . 13

CORRECTIONS OF CALCULATIONAL BIAS . . . . . . . . . . . . . 29

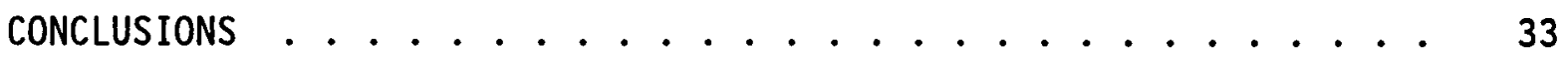

REFERENCES ......................... . . 35

APPENDIX A: PRINCIPLE OF THE MEASUREMENTS . . . . . . . . . . . . A.I

APPENDIX B: EXPERIMENTAL PROCEDURES . . . . . . . . . . . . . B. 1 


\section{FIGURES}

1 HTLTR Experimental History . . . . . . . . . . . . 2

2 Temperature foefficient of Reactivity Calculated for a

Fresh HTGR 233 U Burner Lattice Using ENDF/B-IV Data . . . . . . 3

3 Schematic Illustration of HTLTR and Supporting Facilities . . . 5

4 Front Face of HTLTR with She11 Door Removed . . . . . . . . . . 7

5 HTLTR Graphite Stack at $1000^{\circ} \mathrm{C}$. . . . . . . . . . . . 8

6 HTLTR Control Rods . . . . . . . . . . . . . . . . . 9

7 HTLTR Remote Samiple Changer with Preheating Capabilities . . . 11

8 Typical Fuel Block for HTGR Experiments in HTLTR . . . . . . . 14

Pyrocarbon Coated $\mathrm{PuO}_{2} \mathrm{Microspheres}$ for $\mathrm{ThO}_{2}-\mathrm{PuO}_{2}$
HTGR Lattice . . . . . . . . . . . . . . 15

10 Comparison of Calculated and Measured Neutron Multiplica-

tion Factors as a Function of Temperature . . . . . . . . 17

11 Comparison of Calculated and Measured $k_{\infty}(T)$ Values

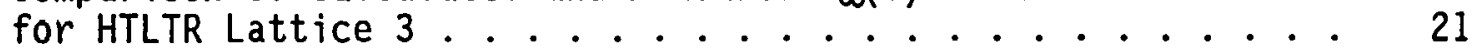

12 Comparison of Calculated and Measured Neutron Multiplica-

tion Factors as a Function of Temperature for HTLTR

Lattice 2..................... . . . 22

13 Comparison of Calculated and Measured $k_{\infty}(T)$ Values for

HTLTR Lattice 5.................. . . . 22

14 Comparison of Calculated and Measured Values of $k_{\infty}$ for

$\mathrm{V}_{2} \mathrm{O}_{3}-\mathrm{PuO}_{2}$ and $\mathrm{ThO}_{2}-\mathrm{PuO}_{2} \mathrm{HTGR}$ Lattices............ 26

15 Comparison of $k_{\infty}(T)$ for ${ }^{235} U C_{2}-V_{2} \mathrm{O}_{3}$ and

$235 \mathrm{UC}_{2}-\mathrm{ThO}_{2} \mathrm{HTGR}$ Lattices . . . . . . . . . . . . . . 28

16 Correction of Temperature Coefficient of Reactivity

Calculated for HTGR Lattices Using ENDF/B-IV Cross

Section Data . . . . . . . . . . . . . . . . . 


\section{$\underline{\text { TABLES }}$}

1 Composition of $235 \mathrm{UC}_{2}-\mathrm{ThO}_{2}$ HTGR Lattice .......... 16

2 Experimental and Calculated Parameters for a $235 \mathrm{UC}_{2}-\mathrm{ThO}_{2}$ Lattice ................. . . 17

3 Composition of $233 \mathrm{UO}_{2}-\mathrm{ThO}_{2}$ DiTute HTGR Lattice . . . . . . 18

4 Composition of $233 \mathrm{UO}_{2}-\mathrm{ThO}_{2}$ HTGR Lattice .......... . 19

5 Composition of $233 \mathrm{UO}_{2}-\mathrm{ThO}_{2}$ HTGR Lattice

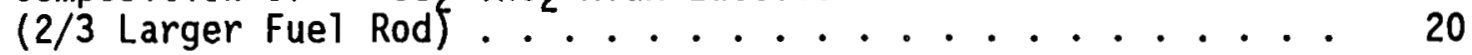

6 Experimental and Calculated $k_{\infty}(T)$ Values for a Dilute

$23 \mathrm{UO}_{2}-\mathrm{ThO}_{2}$ HTGR Lattice............... 23

7 Experimental and Calculated $k_{\infty}(T)$ Values for a $233 \mathrm{UO}_{2}-\mathrm{ThO}_{2}$ HTGR Lattice ................ 23

8 Experimental and Calculated $\mathrm{k}_{\infty}(T)$ Values for a $233 \mathrm{UO}_{2}-\mathrm{ThO}_{2}$ HTGR Lattice $(2 / 3$ larger fuel rod) ........... 23

9 Composition of $\mathrm{PuO}_{2}-\mathrm{ThO}_{2} \mathrm{HTGR}$ Lattice .......... 24

10 Experimental and Calculated $\mathrm{K}_{\infty}(\mathrm{T})$ Values for a $\mathrm{PuO}_{2}-\mathrm{ThO}_{2}$ HTGR Lattice ................. 27

11 Comparison of Least-Squares Correlation Coefficients for $k_{\infty}(T)$ Values Calculated for Each HTGR Lattice Tested in the HTLTR . . . . . . . . . . . . . . 


\section{INTRODUCTION}

The reactivity behavior of a high-temperature gas-cooled reactor (HTGR), which uses helium gas as coolant, is insensitive to changes in coolant density. As a result, reactivity control of graphite-moderated HTGRs is simplified from that of light-water reactors (LWRs) or heavy-water reactors (HWRs), where the moderator is also the coolant and can undergo a phase change. In addition, an HTGR has a large thermal capacity in the core that can absorb excess heat without rapid changes in fuel or moderator temperatures. However, a negative temperature coefficient of reactivity both for the fuel kernels (prompt) and for the entire lattice (isothermal) is necessary at all stages of operation to provide a stabilizing feedback effect to cope with reactivity insertions and transients. A11 anticipated reactivity control functions in an HTGR, such as shim, burnup, and power distribution control, are performed by control rods that can be moved vertically in channels provided in some of the fuel block stacks.

The prismatic HTGR fuel block was developed by General Atomic in the late 1960 s to eliminate some problems encountered with full-length tubular fuel elements employed in the early HTGR prototype, Peach Bottom-1. Prismatic fuel blocks were used in the 330 MWe Ft. St. Vrain (FSV) HTGR that was operated by Public Service Co. of Colorado in the 1970s and early 1980s. To support the development and licensing efforts on FSV, the U.S. Atomic Energy Commission funded the design, construction, and operation of the HighTemperature Lattice Reactor (HTLTR) at the Pacific Northwest Laboratory. The HTLTR was the only facility capable of measuring the isothermal reactivity behavior of HTGR cores up to $1300 \mathrm{~K}$ with high precision. PNL conducted experiments with five different HTGR cores in the HTLTR between 1968 and 1971. The chronology of these HTLTR operations is shown in Figure 1. These experiments included measurements of the temperature-dependent neutron multiplication factor, $k_{\infty}(T)$, temperature coefficients of reactivity, thorium Doppler coefficient, and other integral neutronic data. Results of the HTLTR experiments provided the basis for validation of GA and PNL calculational methods and cross-section data used for HTGR neutronic design and safety analysis and to quantify the bias in calculated predictions of temperature coefficients of reactivity in HTGR lattices. 


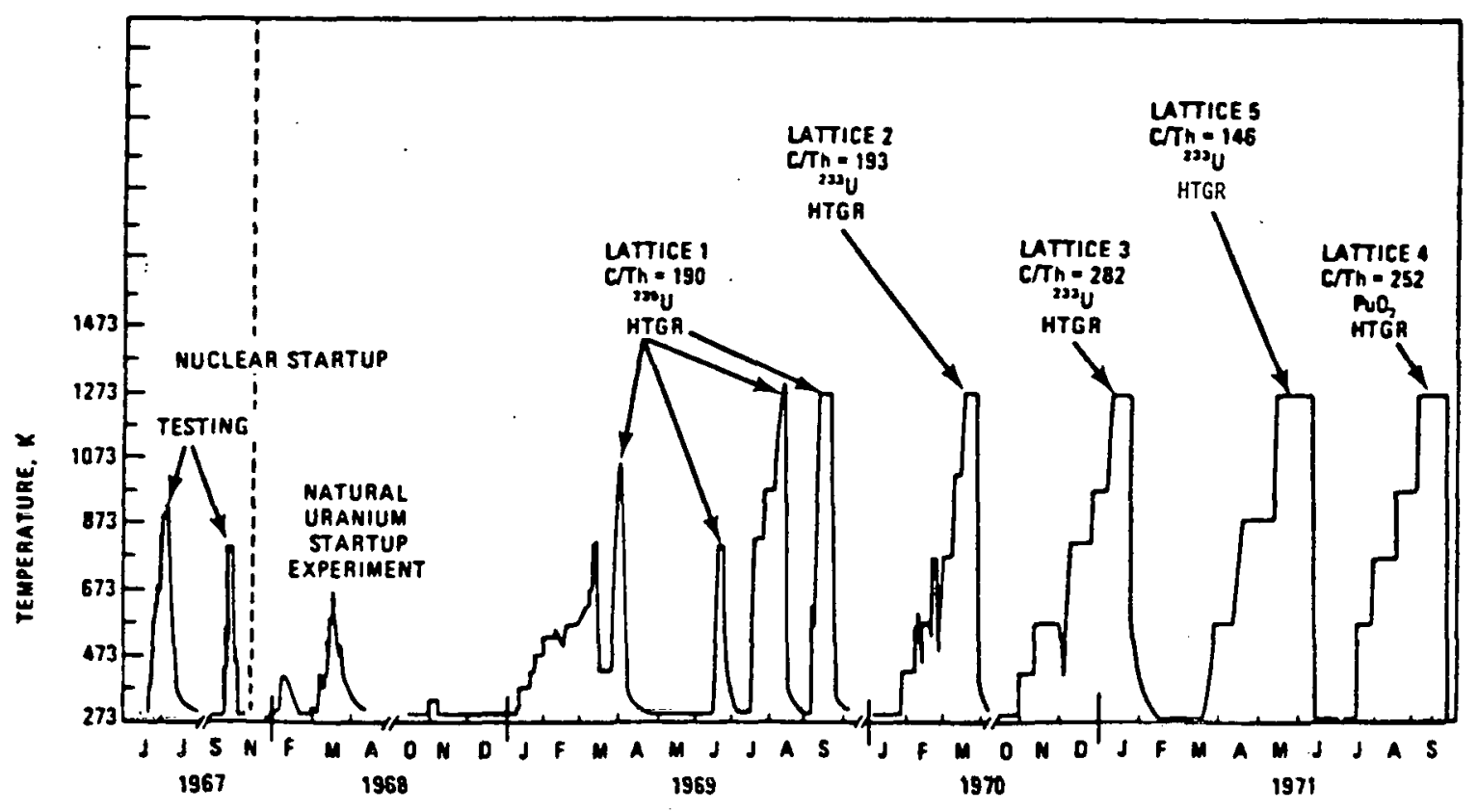

FIGURE 1. HTLTR Experimental History

The FSV HTGR used highly enriched uranium and thorium fuel. The thorium content provided the main negative contribution to the prompt and isothermal temperature coefficients of reactivity through the Doppler effect on the neutron capture resonances of thorium. At the beginning-of-life of an HTGR core, other significant contributions to the temperature coefficient of reactivity are due to effects from $235 \mathrm{U}$, 1 umped burnable poison, inserted control rods, and neutron leakage. Three of the HTGR cores operated in the HTLTR contained $233 \mathrm{U}$ and thorium. These compositions were selected to determine variations in the temperature coefficients of reactivity in an HTGR due to buildup of $233 \mathrm{U}$ in-situ and recycle operations. (1) Predicted values of the temperature coefficient of reactivity for fresh $233 \mathrm{U}$ recycle HTGR lattice are negative at temperatures below $1600 \mathrm{~K}$, as shown in Figure 2, due to the Doppler effect on thorium resonance neutron capture. 


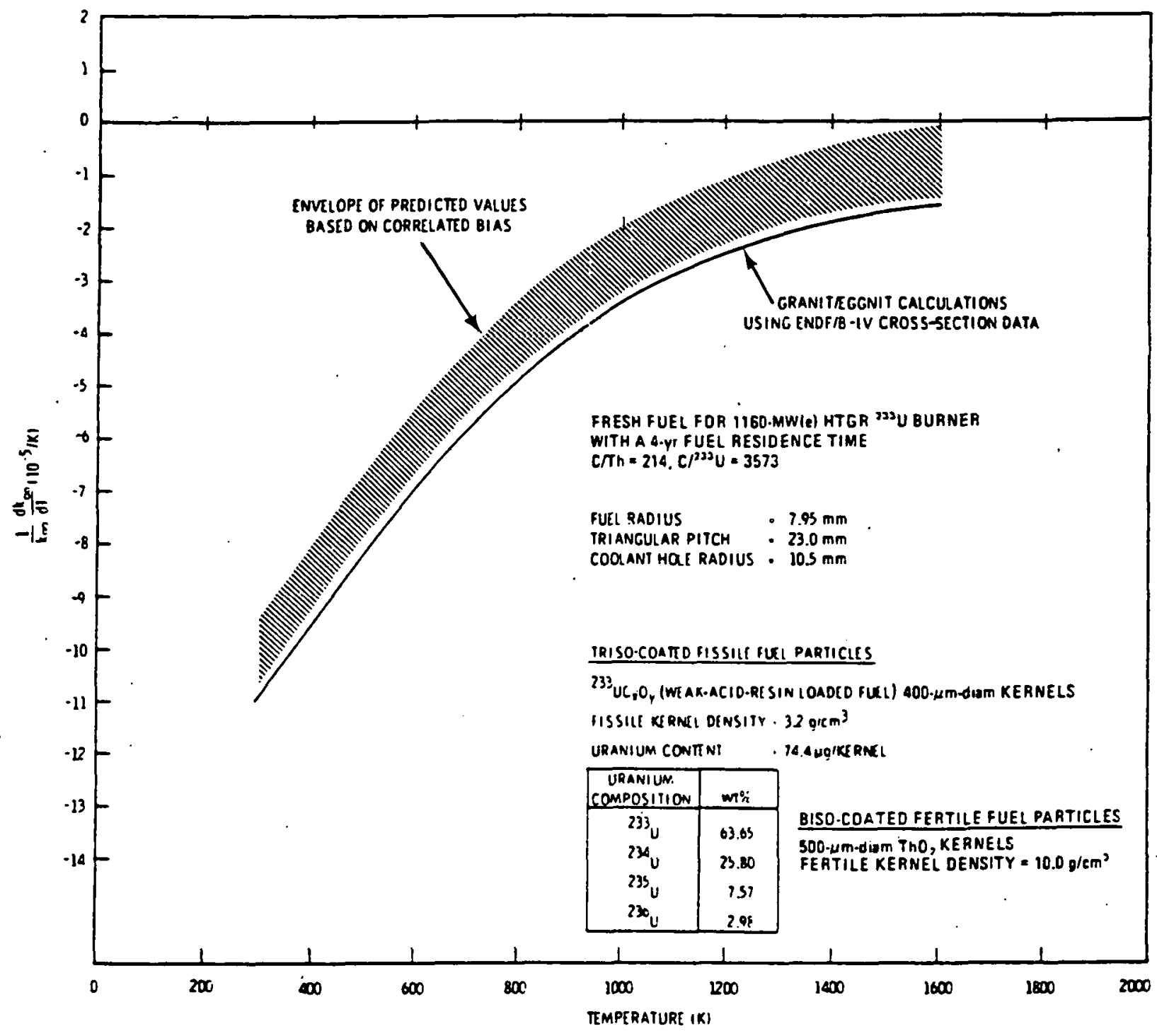

FIGURE 2. Temperature Coefficient of Reactivity Calculated for a Fresh HTGR 233 U Burner Lattice Using ENDF/B-IV Data 
The design of the HTLTR facility was drawn from the experience of a number of predecessors in the field of heated critical assemblies, HERO(2) in Great Britain, CESAR $(3)$ in France, and HOT BOX $(4)$ in the United States. Some of its features were unique, however. In particular, the capability to operate at an ambient temperature of $1000^{\circ} \mathrm{C}\left(1273 \mathrm{~K}, 1832^{\circ} \mathrm{F}\right)$, for extended periods of time (several weeks) and to make precise measurements of reactivity worth of sample lattice materials while at temperature was not equaled anywhere.

The HTLTR and its supporting facilities are shown in Figure 3 . The reactor consisted of a $10-\mathrm{ft}$ cube of graphite enclosed in a carbon stee 1 shell oven which was thermally insulated and gas tight.

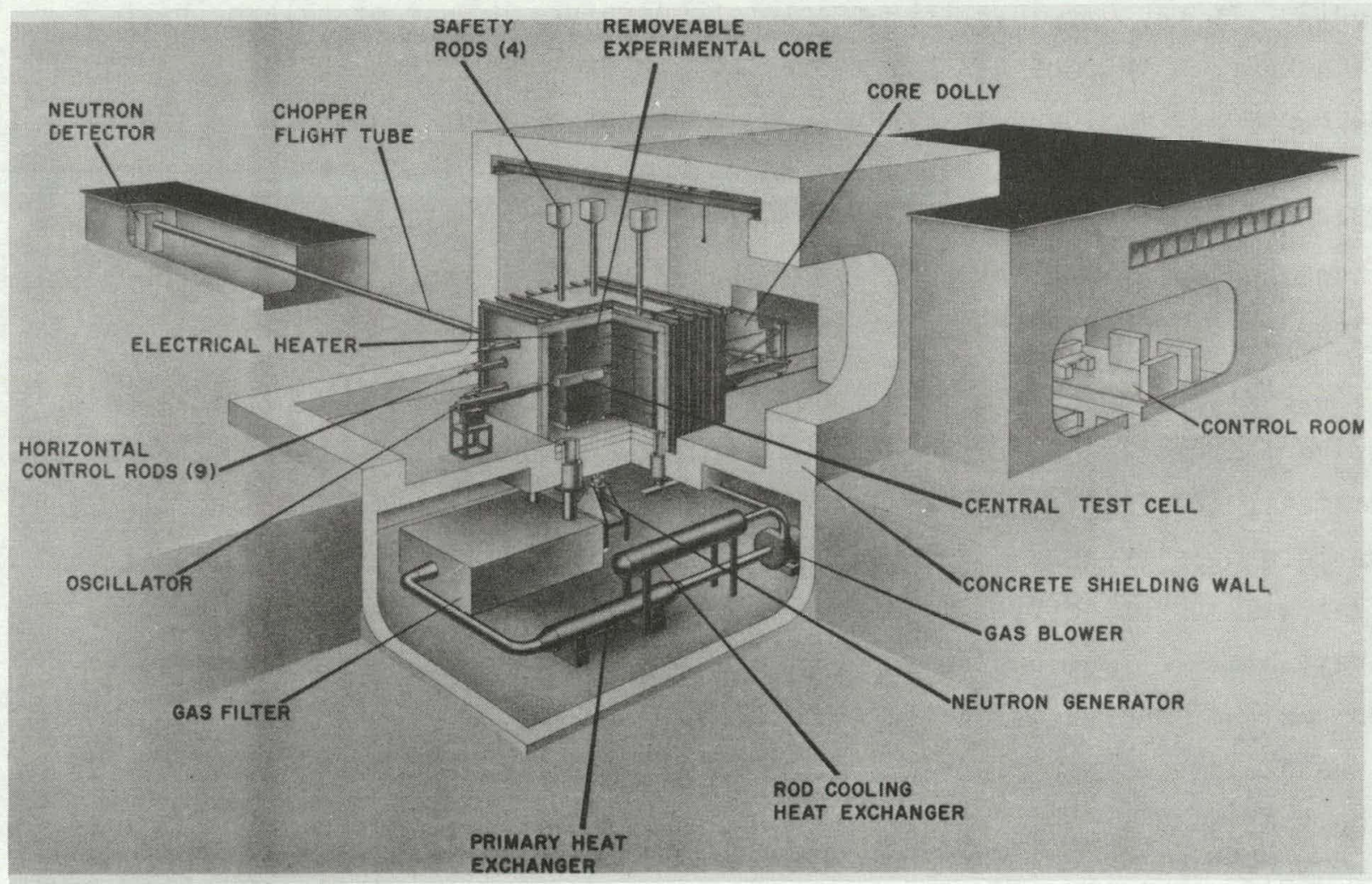

FIGURE 3. Schematic I17ustration of HTLTR and Supporting Facilities 
The reactor was made up of cored, nuclear grade graphite bars which were stacked, keyed, and doweled together to form a solid unit. The 5-ft-square by $10-\mathrm{ft}$-long central section was removable to permit loading of different test assemblies. The central test cell of an experimental core could thereby be provided with a flux environment characteristic of its own kind of cells in a critical array. Driver fuel and control rods were located in symmetric positions surrounding the test section. The reactor, rated at $2 \mathrm{~kW}$ for nuclear operation, was heated electrically and operated with average temperatures of the graphite cube up to $1000^{\circ} \mathrm{C}$. A maximum of $384 \mathrm{~kW}$ of electrical power could be applied to heat the reactor, using 24 graphite heater bars that extended through the $10-\mathrm{ft}$ length of the graphite stark. A thermally insulated, gas-tight, steel shell around the reactor made the assembly essentially a furnace. Nitrogen gas was used to provide an inert atmosphere to inhibit oxidation of the carbon moderator. The nitrogen also served as a coolant to rapidly lower the reactor temperature by use of a large heat exchanger in the gas system. A photograph of the HTLTR with the front she11 door removed is shown in Figure 4. The front face of the graphite stack is shown with a simulated HTGR test core in place. A viewing port was provided near the front face of the HTLTR shell which permitted observation of sample changing in the reactor at all temperatures. A photograph taken through this viewer at $1000^{\circ} \mathrm{C}$ is shown in Figure 5 .

Enriched uranium driver fuel was used to make the HTLTR critical. The driver assemblies consisted of $\mathrm{UO}_{2}$ ( 5 wt\% $235 \mathrm{U}$ ) ceramic pellets, 1.06 in. in diameter and $1 / 2$ in. thick, loaded into graphite tubes 1.6-in. 0.d. The fue 1 pellets were arranged in the fuel assemblies such that each $1-i n$. length of fuel was separated by $2 \mathrm{in}$. of graphite. Three fuel element lengths were available: 6,10 , and $60 \mathrm{in.}$ The 60 -in.-1ong assemblies were the main driver fuel and were located in a ring around the test core. The shorter length elements were located on the ends of the test core and served to level the spatial distribution of the neutron flux in the longitudinal direction.

Fine control of the neutron multiplication in the HTLTR was maintained by eight shutter-type control rods whose active length was $90 \mathrm{in}$. The control rods were located symmetrically about the axis at a radial distance of $38 \mathrm{in}$. and ran parallel to the axis of the reactor. A ninth rod, having 


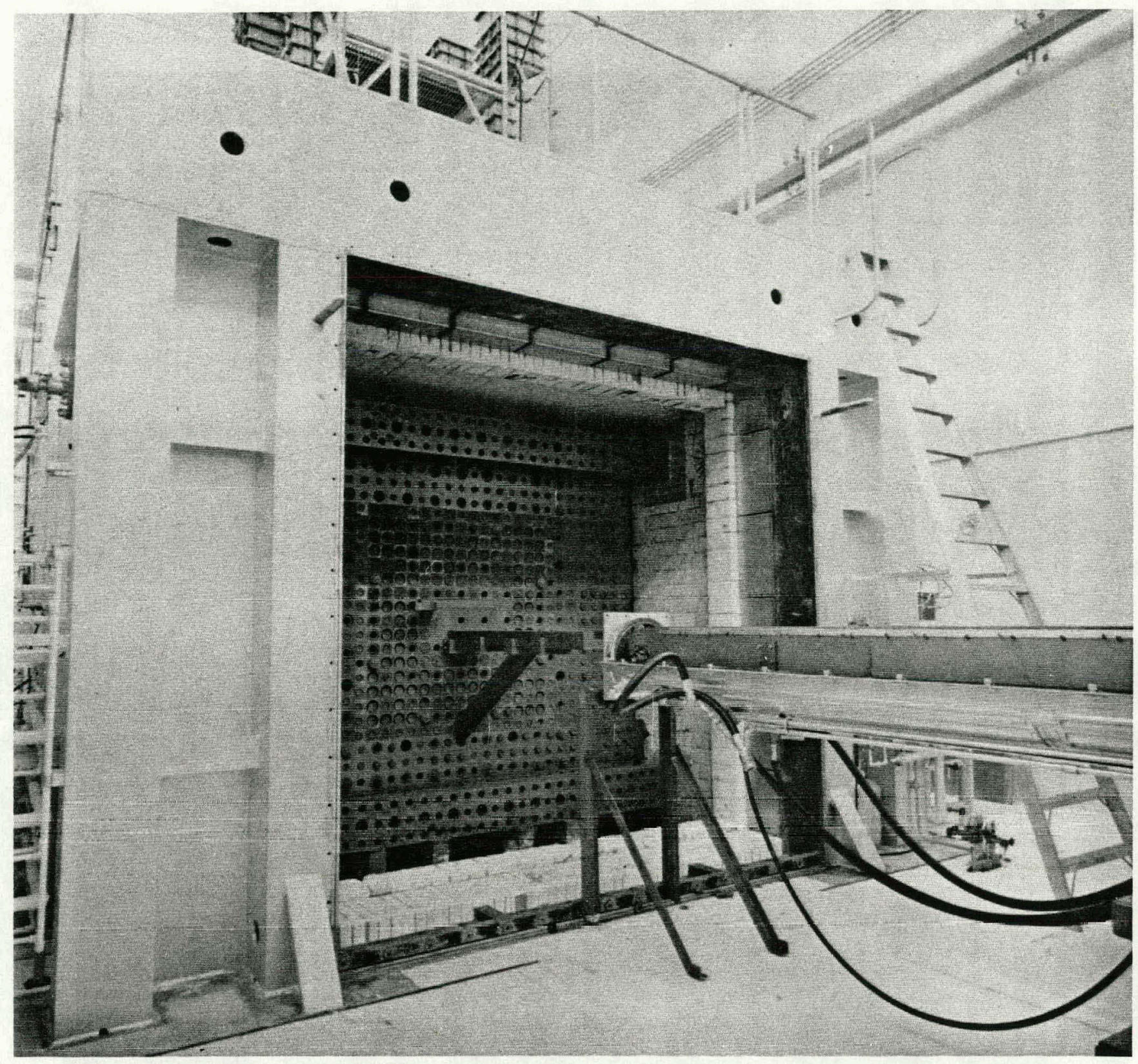

FIGURE 4. Front Face of HTLTR with Shell Door Removed

only a small fraction of the strength of the primary control rod, was provided to obtain precise measurements of small reactivity changes. This rod was located 56 in. from the axis and had an active length of only 30 in. 


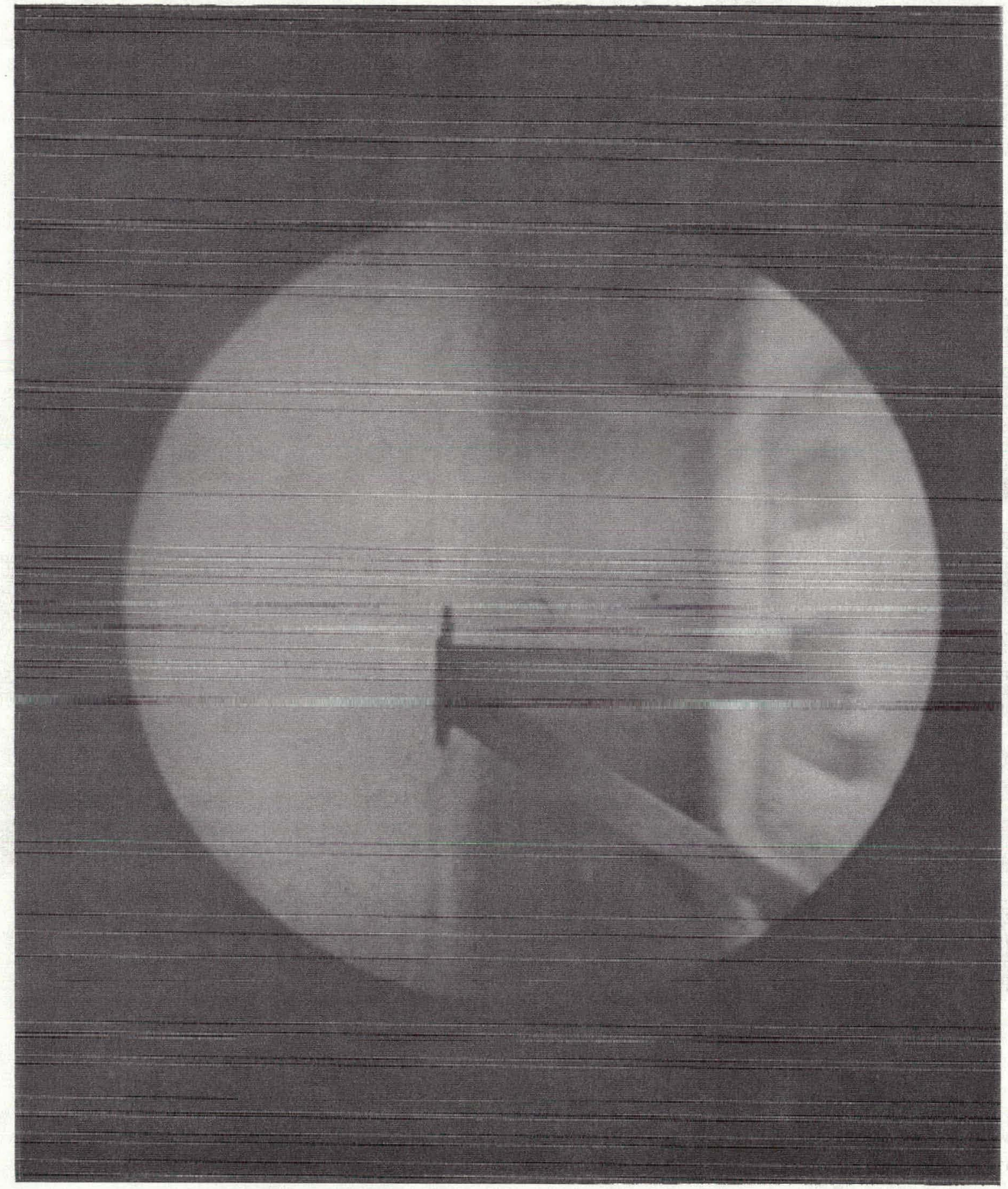

FIGURE 5. HTLTR Graphite Stack at $1000^{\circ} \mathrm{C}$ 
Each control rod, illustrated in Figure 6, consisted of two concentric tubes made up alternately of 6-in.-long graphite cylinders and cylinders of $\mathrm{UO}_{2}$ dispersed in graphite $\left(3 \mathrm{~g} / \mathrm{cm}^{3} \mathrm{UO}_{2}, 16 \mathrm{wt} \% 235 \mathrm{U}\right)$. The outer tube, 2.1-in. o.d. and 1.44-in. i.d., was held stationary with respect to the reactor. The inner tube, 1.37-in. 0.d. and 0.75-in. i.d., was assembled on a 1/2-in.-dia thoria-dispersed nickel (TD nickel) rod which is connected to a driving mechanism located at the rear of the reactor and outside the reactor she11. A change in the reactivity of the reactor was obtained by changing the mutual neutron shielding between the fuel sections of the inner and outer control tubes. In the closed position (position of maximum shielding and least reactivity) the $\mathrm{U}_{2}$-graphite sections of the inner tube appeared under the $\mathrm{UO}_{2}$-graphite sections of the outer tube. For the open position (position of least shielding and maximum reactivity) the $\mathrm{UO}_{2}$-graphite sections of the inner tube appeared under the graphite sections of the outer tube. A full change of reactivity was thus obtained with only a 6 -in. movement of the inner control tube.
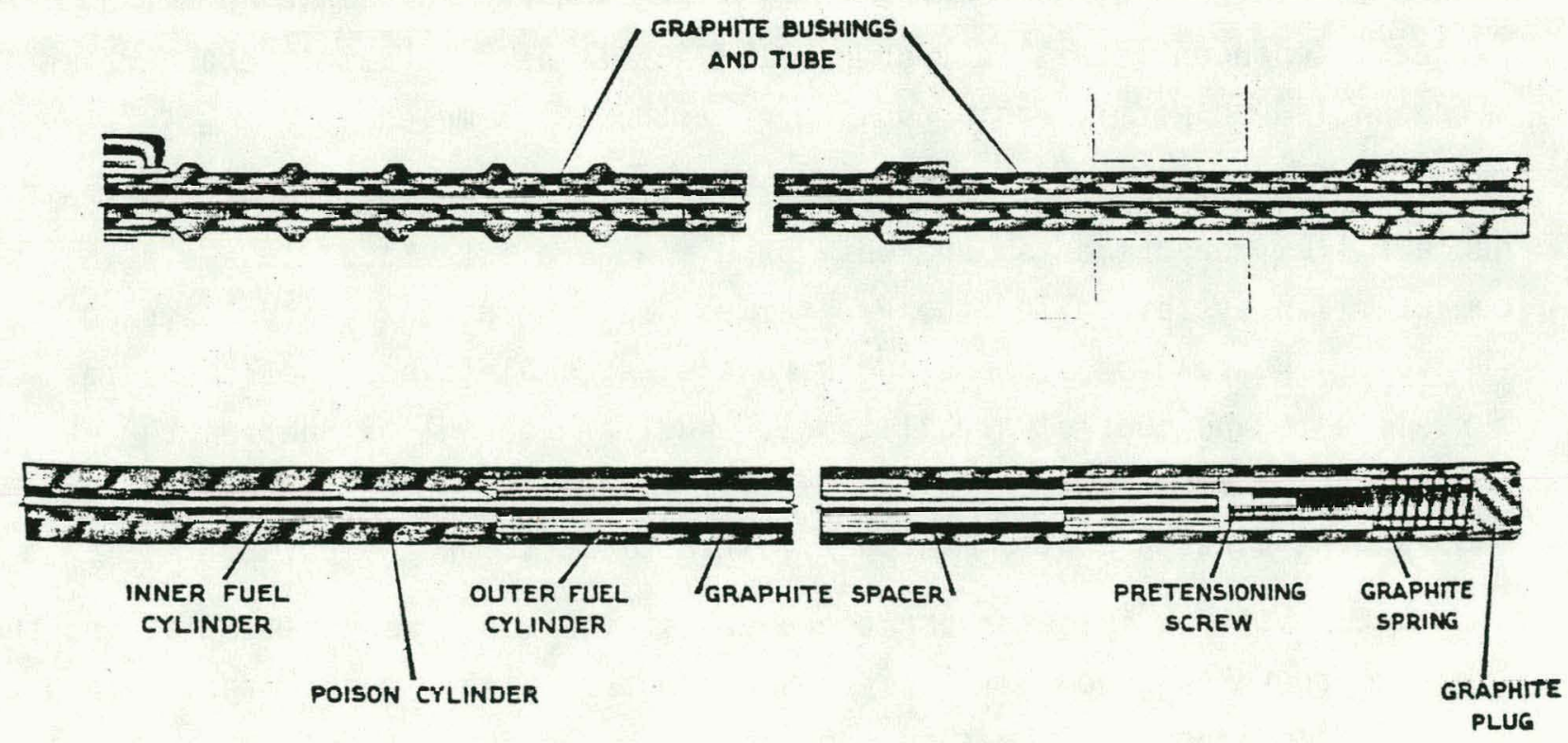

FIGURE 6. HTLTR Control Rods 
A system of four vertical safety blades ensured reactor shutdown capability at all times. Each safety blade was 7 in. wide, about 138 in. long, and $1 / 2$ in. thick. A nickel matrix containing a dispersion of $4 \mathrm{wt} \%$ $\mathrm{Gd}_{2} \mathrm{O}_{3}$ and 4 wt\% $\mathrm{Eu}_{2} \mathrm{O}_{3}$ comprising the neutron absorber, in pieces 6 in. square and 1/16 in. thick, made up an active length of $120 \mathrm{in.}$ These nuclear poison squares were mounted in a ladder frame made up of 1/2-in.-dia. TD-nicke1 rods. Each poison plate was covered on each side with a 0.030-in.-thick TD-nickel sheet which served as a radiant energy shield. The four safety blades moved in vertical rectangular slots located in the reactor moderator.

Two sample changers were available for replacement and repositioning of samples in the reactor at high temperatures with the nitrogen atmosphere in the reactor protected. One of the sample changers was for moving sma11 samples into the reactor; the other sample changer, which is shown in Figure 7, was for heavier samples such as a central test cell. This heavyduty sample changer had an electrically heated oven in it for preheating the samples before insertion in the reactor. Preheating enabled temperature transients during sample changes to be minimized in the HTLTR. Each sample changer could be sealed from the reactor atmosphere and pumped down and purged independently with nitrogen. The shells of both sample changers were water cooled to permit rapid cooling of withdrawn samples.

A11 the sensors and transducers essential for reactor process control, nuclear flux measurements, and data handling were interfaced to a single computerized system called the Programmed Measurement and Control System (PMACS). The reactor systems and hardware were maintained under computer surveillance and control at all times. Nuclear control of the reactor was not a closed loop, however, since reactivity additions to the reactor must be made under operator control through instructions to the computer.

After sitting idle for about ten years, the HTLTR was dismantled and the large concrete-shielded cell that contained the reactor was converted into a radiation dosimetry calibration facility. 


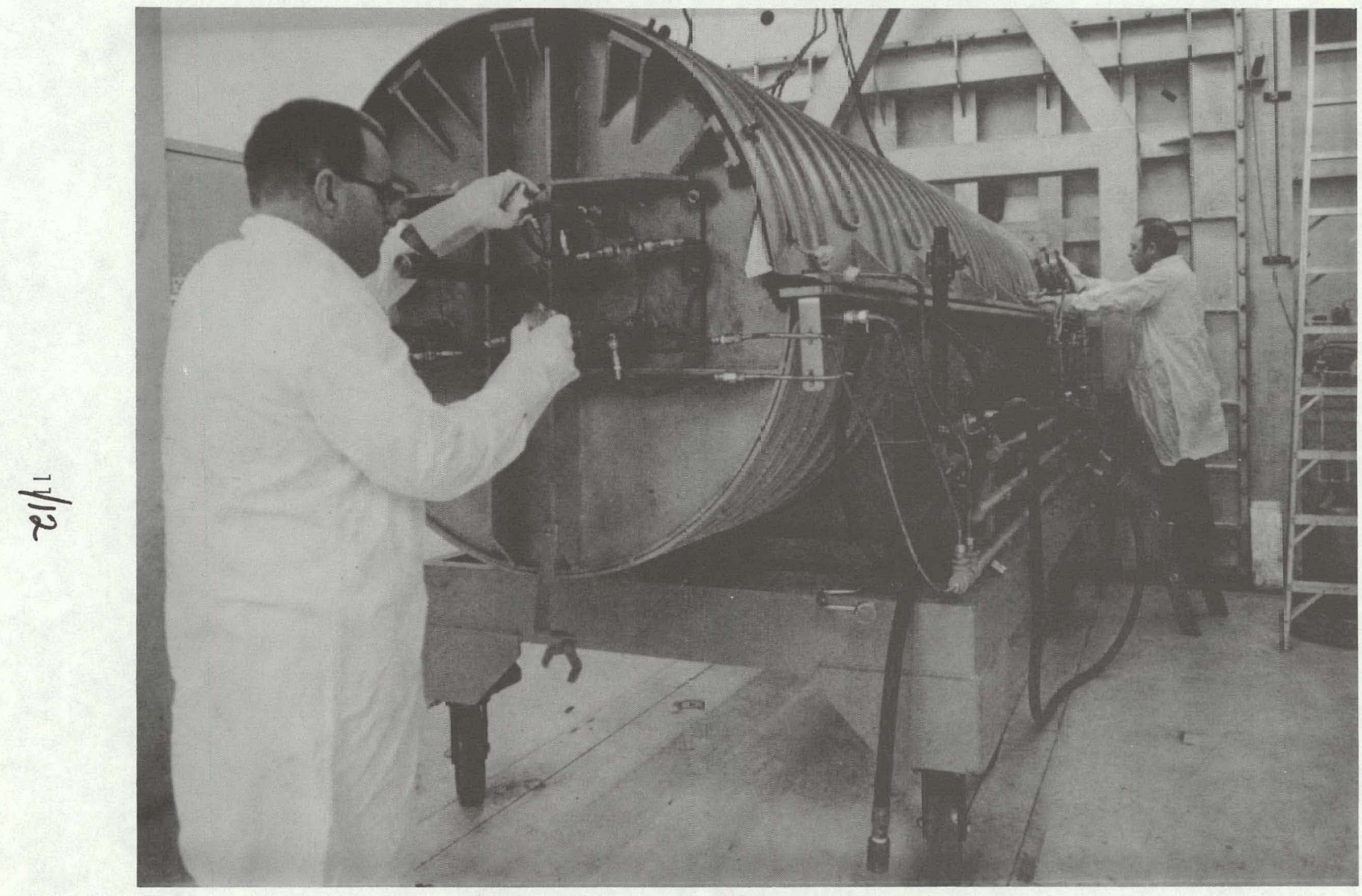

FIGURE 7. HTLTR Remote Sample Changer with Preheating Capabilities 


\section{1 \\ HTGR BENCHMARK DATA}

The HTGR cores tested in the HTLTR used fuel blocks with simplified geometry; no coolant channels were provided. Each HTLTR lattice fuel block was 3.75-in. square. Four of the five HTLTR 1attices used 0.47-in. diameter fue 1 rods on a 0.75 -in. pitch as illustrated in Figure 8 . The fifth lattice used 0.786 -in. diameter fuel rods on a 1.875-in. square pitch. The fissile fuel particles used in the fuel rods were coated with pyrolytic carbon, as shown in Figure 9.

A11 of the HTGR fuel blocks used in the HTLTR were fabricated at PNL. Fissile fuel microspheres enclosed in a pyrocarbon coating were specially prepared at 0ak Ridge National Laboratory (ORNL) for each of the five test cores. The amount of fissile fuel in these coated microspheres was chemically analyzed by ORNL to an estimated accuracy of $1 \%$. Therefore, although the total weight of coated microspheres in each block is accurately known, the amount of fissile material in each block has a $1 \%$ uncertainty. A much smaller uncertainty exists for the total amount of thorium and graphite particles loaded in the fuel channels of each block. The thoria particles were uncoated and consisted of irregular shapes of various sizes. The graphite particles were prepared by collecting powder milled from nucleargrade graphite blocks at PNL. The loading procedure described in reference 21 was used to achieve a homogeneous fue 1 distribution throughout each fuel channel. Loaded blocks were X-rayed as an overall check of uniformity.

A sufficient number of blocks (about 150) of each core composition were loaded in the center of the HTLTR to establish the equilibrium neutron spectrum characteristic of a critical assembly of each core being tested. Values of the neutron multiplication factor, $k_{\infty}$, were measured at several temperatures for each HTGR core being tested.

Using the composition and geometry known for each of the test cores, values of $k_{\infty}$ were calculated for each core as a function of temperature. The GRANIT (5) and EGGNIT(6) codes were used for these calculations using ENDF/B-IV neutron cross-section data. These codes are capable of handling multiregion and granular composite geometries encountered in HTGR fuel assemblies. The GRANIT code calculates the spatially dependent 


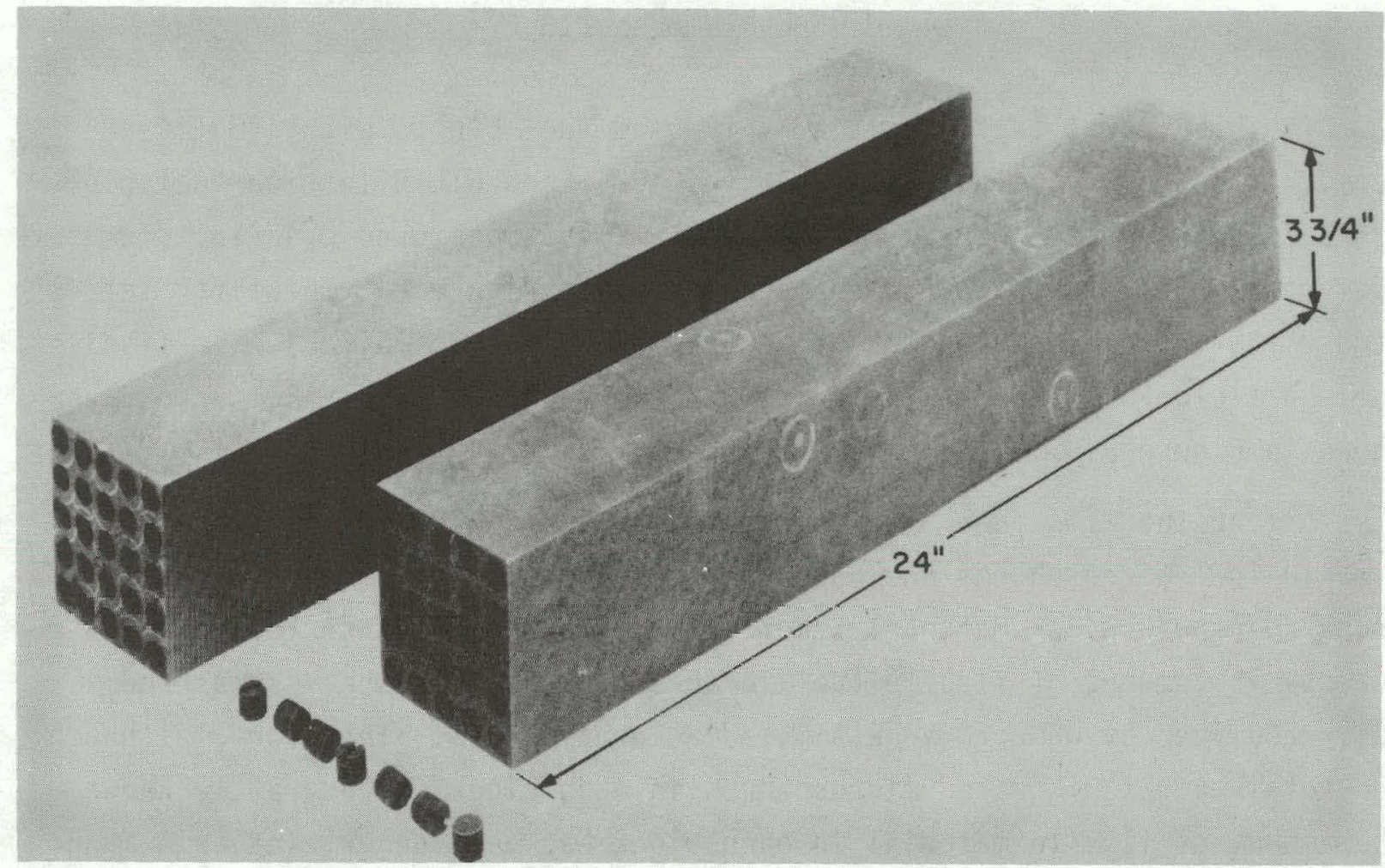

FIGURE 8. Typical Fuel Block for HTGR Experiments in the HTLTR

thermal-neutron spectra, reaction rates, and spectrum-averaged neutronic parameters for a unit lattice cell of an HTGR using 48 energy groups below $3.06 \mathrm{eV}$. The EGGNIT code calculates resonance self-shielding, neutron spectra, and reaction rates for the lattice cell in 60 energy groups from $10 \mathrm{MeV}$ to $3.06 \mathrm{eV}$. These neutron spectra calculations, using the $\mathrm{B}_{1}$ approximation, are coupled using the critical equation

$$
k_{e f f}=1=\frac{k_{\infty}\left[1+(1-p) L^{2} B^{2}\right]}{\left(1+\tau B^{2}\right)\left(1+L^{2} B^{2}\right)}
$$




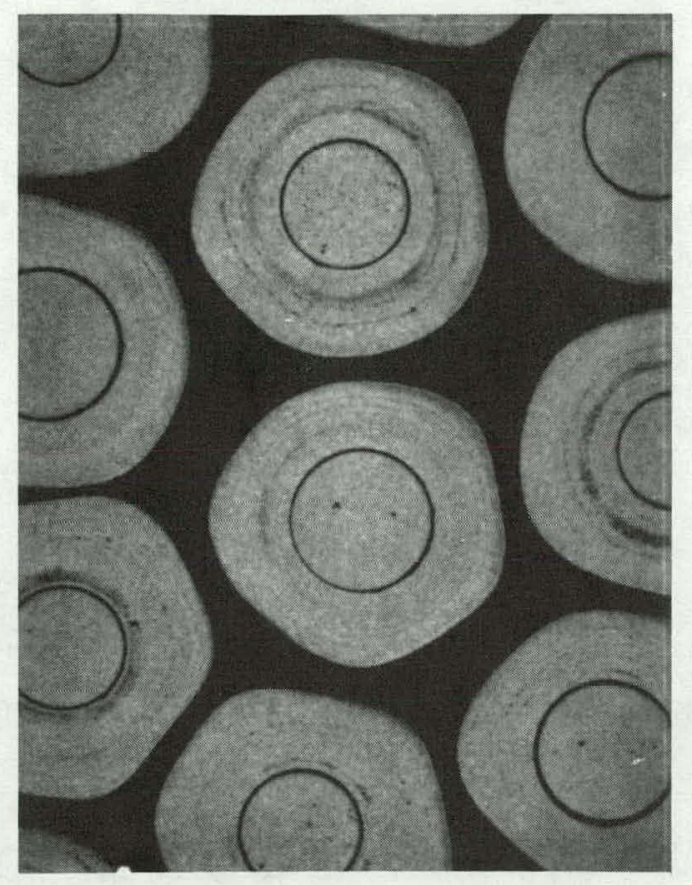

FIGURE 9. Pyrocarbon Coated $\mathrm{PuO}_{2}$ Microspheres for $\mathrm{ThO}_{2}-\mathrm{PuO}_{2}$ HTGR Lattice

where

$$
\begin{aligned}
& k_{\infty}=\frac{\eta_{1} f_{1}(1-p)\left(1+L^{2} B^{2}\right)+\eta_{2} f_{2} p}{1+(1-p) L^{2} B^{2}}, \\
& \tau=\frac{D_{1}}{\Sigma_{1 \rightarrow 2}+\Sigma a_{1}}, \eta_{1} f_{1}=\left(\frac{\nu \Sigma_{f}}{\Sigma a}\right)_{1}, \quad \eta_{2} f_{2}=\left(\frac{\nu \Sigma_{f}}{\Sigma a}\right)_{2}, \\
& p=\frac{\Sigma_{1 \rightarrow 2}}{\Sigma_{1 \rightarrow 2}+\Sigma a_{1}}, L^{2}=\frac{D_{2}}{\Sigma a_{2}}
\end{aligned}
$$

and $B^{2}$ is the material buckling which satisfies both equations (1) and (2).

Compositions for the ${ }^{235} \mathrm{UC}_{2}-\mathrm{ThO}_{2}$ HTGR lattice are 1isted in Table 1; the $\mathrm{C} / \mathrm{Th}$ atom ratio is 190 and the $\mathrm{C} / 235 \mathrm{U}$ atom ratio is 5710 . (7) The $\mathrm{C} / \mathrm{Th}$ atom ratio is similar to that of FSV and the highly enriched $235 \mathrm{U}$ particulate fuel 
TABLE 1. Composition of $235 \mathrm{UC}_{2}-\mathrm{ThO}_{2}$ HTGR Lattice

Concentration (atoms/b-cm)

\begin{tabular}{|c|c|c|c|c|c|}
\hline Nuclide & $\begin{array}{c}\mathrm{UC}_{2} \\
\text { Particles }\end{array}$ & $\begin{array}{c}\mathrm{ThO}_{2} \\
\text { Particles }\end{array}$ & $\begin{array}{l}\text { Fuel Rod } \\
\text { Region } \\
\end{array}$ & $\begin{array}{l}\text { Moderator } \\
\text { Region }\end{array}$ & $\begin{array}{l}\text { Homogenized } \\
\text { Cell Average }\end{array}$ \\
\hline $234 U$ & $1.39-04$ & -- & $2.42-07$ & -- & $7.45-08$ \\
\hline $235 U$ & $2.27-02$ & -- & $3.94-05$ & -- & $1.22-05$ \\
\hline $236 U$ & $7.30-05$ & -- & $1.27-07$ & -- & $3.91-08$ \\
\hline $238 U$ & $1.30-03$ & -- & $2.26-06$ & -- & $6.97-07$ \\
\hline${ }^{232} \mathrm{Th}$ & -- & $2.28-02$ & $1.18-03$ & -- & $3.65-04$ \\
\hline 0xygen & -- & $4.56-02$ & $2.37-03$ & -- & $7.30-04$ \\
\hline Nitrogen (a) & -- & -- & $2.66-05$ & $1.40-05$ & $1.79-05$ \\
\hline Carbon & $4.84-02$ & -- & $4.63-02$ & $7.98-02$ & $6.95-02$ \\
\hline
\end{tabular}

(a) At $296 \mathrm{~K}$. For other temperatures $N_{n}(T)=N_{n}(296) \frac{296}{T(K)}$

$\mathrm{C} / \mathrm{Th}=190, \mathrm{C} / 235 \mathrm{U}=5710$. (HTLTR Lattice 1 )

Fuel rod radius $=0.5969 \mathrm{~cm}$.

Square lattice pitch $=1.905 \mathrm{~cm}$.

\begin{tabular}{|c|c|c|c|c|}
\hline \multicolumn{3}{|c|}{$\begin{array}{c}\text { Distribution of } \mathrm{ThO}_{2} \text { Particle } \\
\text { Sizes }\end{array}$} & \multicolumn{2}{|c|}{$\begin{array}{c}\text { Distribution of } U C_{2} \text { Particle } \\
\text { Sizes }\end{array}$} \\
\hline $\begin{array}{l}\text { Particle Diameter } \\
\text { Range }(\mu \mathrm{m}) \\
\end{array}$ & $\begin{array}{l}\text { Average Particle } \\
\text { Diameter }(\mathrm{cm})\end{array}$ & $\begin{array}{l}\text { Weight } \\
\text { Percent }\end{array}$ & $\begin{array}{l}\text { Average Particle } \\
\text { Diameter }(\mathrm{cm})\end{array}$ & $\begin{array}{l}\text { Weight } \\
\text { Percent }\end{array}$ \\
\hline $0-44$ & 0.0022 & 49.4 & 0.0270 & 19 \\
\hline $44-74$ & 0.0059 & 16.4 & 0.0290 & 26 \\
\hline $74-105$ & 0.00895 & 19.4 & 0.0320 & 20 \\
\hline $105-149$ & 0.0127 & 11.1 & 0.0340 & 17 \\
\hline $149-210$ & 0.01795 & 3.1 & 0.0370 & 10 \\
\hline & & & 0.0390 & 8 \\
\hline
\end{tabular}

is of the same type used in FSV. Results of comparisons of experimental and calculated $\mathrm{k}_{\infty}$ values for the $235 \mathrm{UC}_{2}-\mathrm{ThO}_{2}$ HTGR lattice are shown in Figure 10 and listed in Table 2.(8)

Compositions for the three $233 \mathrm{UO}_{2}-\mathrm{ThO}_{2} \operatorname{HTGR}$ lattices $(9,10,11)$ are listed in Tables 3,4 , and 5 . The $\mathrm{C} / \mathrm{Th}$ atom ratio for these lattices are 282, 193, and 146. The $233 \mathrm{UO}_{2}-\mathrm{ThO}_{2}$ particles are about $300 \mu$ diameter and have a Th/U atom ratio of 3 . Additional particles of pure $\mathrm{ThO}_{2}$ were added to 


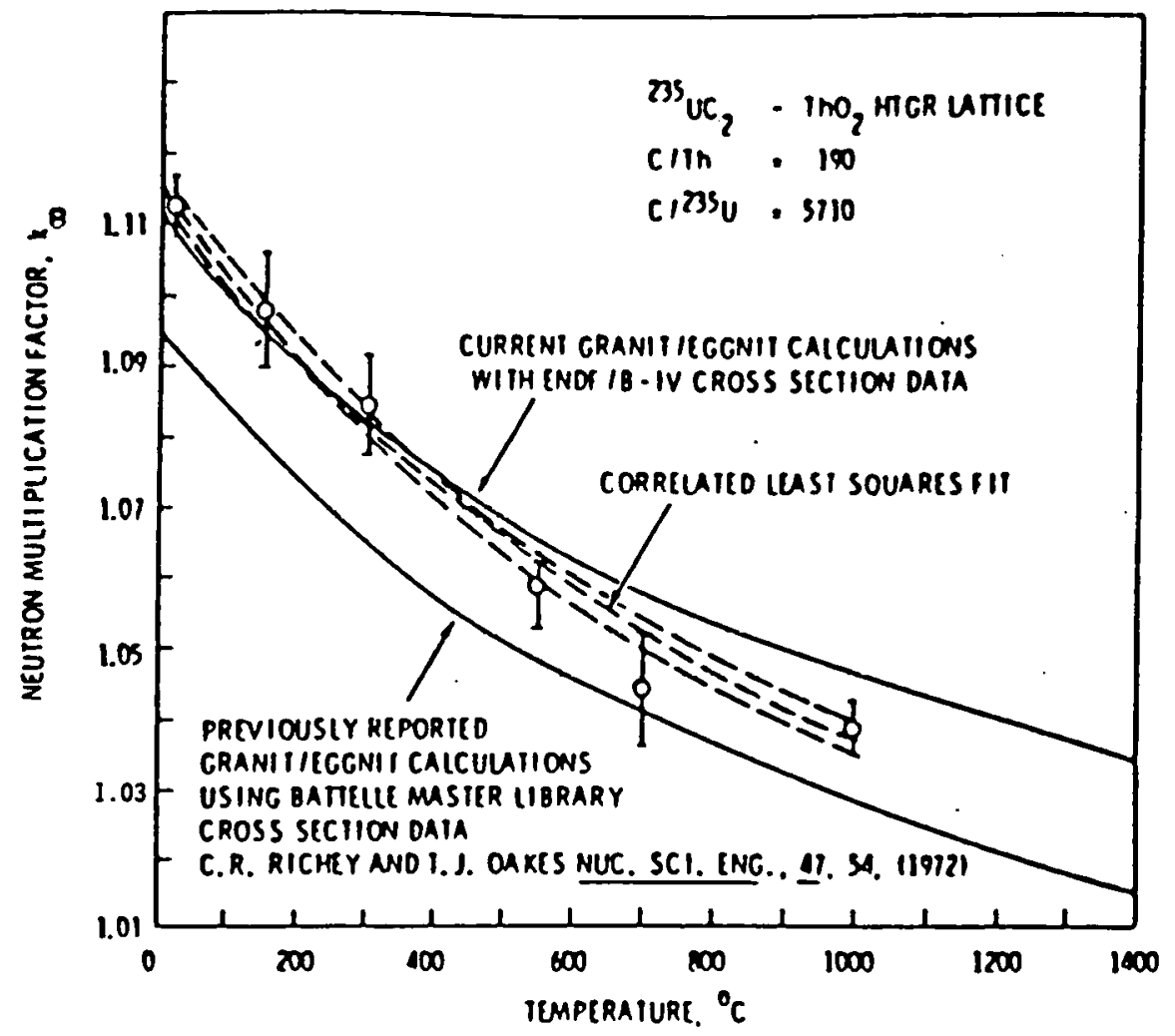

FIGURE 10. Comparison of Calculated and Measured Neutron Multiplication Factors as a Function of Temperature

TABLE 2. Experimental and Calculated Parameters for a $235 \mathrm{UC}_{2}-\mathrm{ThO}_{2}$ Lattice

(HTLTR Lattice 1); GRANIT/EGGNIT Calculations (8) Used ENDF/B-IV Cross-Section Data

\begin{tabular}{|c|c|c|c|}
\hline \multirow[b]{2}{*}{$\begin{array}{c}\text { Temperature } \\
(\mathrm{K})\end{array}$} & \multicolumn{2}{|c|}{ Experimental Values } & $\begin{array}{c}\text { Calculated } \\
\text { Values }\end{array}$ \\
\hline & $\begin{array}{c}\text { Measured } \\
k_{\infty}\end{array}$ & $\begin{array}{c}\text { Best Theory } \\
\text { Least-Squares-Fit } \\
\text { to Measured Data } \\
\end{array}$ & $\begin{array}{c}\text { All Data from } \\
\text { ENDF/B-IV } \\
k_{\infty} \\
\end{array}$ \\
\hline 293 & $1.1126 \pm 0.004$ & 1.1124 & 1.1093 \\
\hline 423 & $1.0979 \pm 0.008$ & 1.0965 & 1.0950 \\
\hline 573 & $1.0845 \pm 0.007$ & 1.0821 & 1.0823 \\
\hline 823 & $1.0591 \pm 0.006$ & 1.0628 & 1.0659 \\
\hline 973 & $1.0444 \pm 0.008$ & 1.0537 & 1.0585 \\
\hline 1273 & $1.0388 \pm 0.004$ & 1.0387 & 1.0468 \\
\hline
\end{tabular}


TABLE 3. Composition of ${ }^{233} \mathrm{UO}_{2}-\mathrm{ThO}_{2}$ Dilute HTGR Lattice

\begin{tabular}{|c|c|c|c|c|c|}
\hline \multirow[b]{2}{*}{ Nuclide } & \multicolumn{5}{|c|}{ Concentration (atom/b-cm) } \\
\hline & $\begin{array}{l}\mathrm{UO}_{2} \text {-Th0 } \\
\text { Particles }\end{array}$ & $\begin{array}{c}\mathrm{ThO}_{2} \\
\text { Particles }\end{array}$ & $\begin{array}{l}\text { Fuel Rod } \\
\text { Region } \\
\end{array}$ & $\begin{array}{l}\text { Moderator } \\
\text { Region }\end{array}$ & $\begin{array}{c}\text { Homogenized } \mathrm{Ce} 71 \\
\text { Average } \\
\end{array}$ \\
\hline $233 U$ & $5.57-03$ & -- & $1.63-05$ & - & $5.04-06$ \\
\hline $234 \mathrm{U}$ & $5.93-05$ & -- & $1.74-07$ & -- & $5.36-08$ \\
\hline $235 U$ & $5.50-06$ & -- & $1.61-08$ & -- & $4.97-09$ \\
\hline $236 U$ & $3.39-07$ & -- & $9.93-10$ & -- & $3.06-10$ \\
\hline $238 U$ & $8.00-05$ & - & $2.35-07$ & -- & $7.24-08$ \\
\hline${ }^{232} \mathrm{Th}$ & $1.71-02$ & $2.28-02$ & $8.11-04$ & -- & $2.50-04$ \\
\hline Oxygen & $4.56-02$ & $4.58-02$ & $1.65-03$ & -- & $5.10-04$ \\
\hline Nitrogen $(d)$ & -- & -- & $2.69-05$ & $1.47-05$ & $1.85-05$ \\
\hline Carbon & -- & -- & 4.88-02 & $8.01-02$ & $7.04-02$ \\
\hline Boron & -- & -- & $1.13-06$ & -- & $3.49-07$ \\
\hline
\end{tabular}

(a) At $296 \mathrm{~K}$. For other temperatures, $N_{n}(T)=N_{n}(296) \frac{296}{T(K)}$.

$C / T h=282, C / 233 U=13,990$. (HTLTR Lattice 3).

Fuel rod radius $=5.969 \mathrm{~mm}$.

Square lattice pitch $=19.05 \mathrm{~mm}$.

$\mathrm{UO}_{2} \mathrm{O}-\mathrm{ThO}_{2}$ particle diameter $=0.322 \mathrm{~mm}$.

Distribution of Th0 2 Particle Sizes

$\begin{array}{cccc}\begin{array}{c}\text { Particle Diameter } \\ \text { Range }(\text { um) }\end{array} & & \begin{array}{c}\text { Average Particle } \\ \text { Diameter (mm) }\end{array} & \begin{array}{c}\text { Weight } \\ \text { Percent }\end{array} \\ 0-44 & & 0.022 & 15.0 \\ 44-74 & 0.059 & 10.5 \\ 74-105 & & 0.0895 & 11.5 \\ 105-149 & 0.127 & 15.0 \\ 149-210 & 0.1795 & 22.0 \\ >210 & 0.250 & 26.0\end{array}$


TABLE 4. Composition of $233 \mathrm{UO}_{2}-\mathrm{ThO}_{2}$ HTGR Lattice

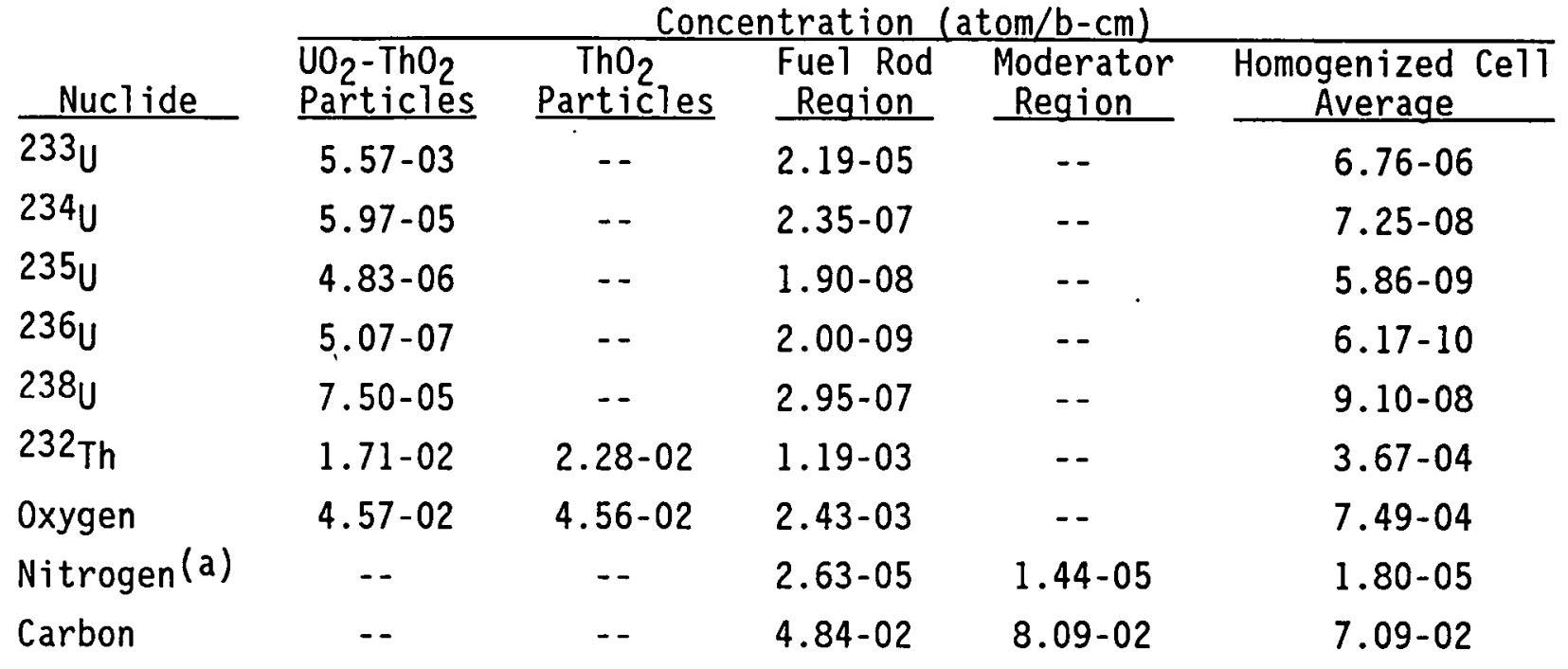

(a) At $296 \mathrm{~K}$. For other temperatures, $N_{n}(T)=N_{n}(296) \frac{296}{T(K)}$. $C / T h=193, C / 233 U=10,470$. (HTLTR Lattice 2)

Fuel rod radius $=5.969 \mathrm{~mm}$.

Square lattice pitch $=19.05 \mathrm{~mm}$.

$\mathrm{UO}_{2}-\mathrm{ThO}_{2}$ particle diameter $=0.280 \mathrm{~mm}$.

\begin{tabular}{ccc}
\multicolumn{2}{c}{ Distribution of $\mathrm{Th}_{2}$} & Particle Sizes \\
\hline $\begin{array}{c}\text { Particle Diameter } \\
\text { Range }(\mu \mathrm{m})\end{array}$ & $\begin{array}{c}\text { Average Particle } \\
\text { Diameter }(\mathrm{mm})\end{array}$ & $\begin{array}{c}\text { Weight } \\
\text { Percent }\end{array}$ \\
$0-44$ & 0.022 & 49.4 \\
$44-74$ & 0.059 & 16.4 \\
$74-105$ & 0.0895 & 19.4 \\
$105-149$ & 0.127 & 11.1 \\
$149-210$ & 0.1795 & 3.7
\end{tabular}

the fuel rods to achieve the desired compositions. Results of comparisons of experimental and calculated $k_{\infty}$ values for the $233 \mathrm{UO}_{2}-\mathrm{ThO}_{2}$ HTGR lattices are shown in Figures 11,12 , and 13; numerical values are 1 isted in Tables 6,7 , and 8 . 
TABLE 5. Composition of $233 \mathrm{UO}_{2}-\mathrm{ThO}_{2}$ HTGR Lattice (2/3 larger fuel rod)

\begin{tabular}{|c|c|c|c|c|c|}
\hline Nuclide & $\begin{array}{l}\mathrm{UO}_{2} \text {-Th0 } \\
\text { Particles }\end{array}$ & $\begin{array}{c}\mathrm{ThO}_{2} \\
\text { Particles }\end{array}$ & $\begin{array}{l}\text { Fuel Rod } \\
\text { Region } \\
\end{array}$ & $\begin{array}{l}\text { tom/b-cm) } \\
\begin{array}{l}\text { Moderator } \\
\text { Region }\end{array} \\
\text { PRe }\end{array}$ & $\begin{array}{c}\text { Homogenized Cel1 } \\
\text { Average }\end{array}$ \\
\hline $233 U$ & $5.74-03$ & $\ldots$ & $5.69-05$ & -. & $7.85-06$ \\
\hline $234 U$ & $6.13-05$ & -- & $6.08-07$ & -- & $8.39-08$ \\
\hline $235 U$ & $5.37-06$ & - & $5.32-08$ & -- & $7.34-09$ \\
\hline $236 U$ & $4.04-07$ & - & $4.00-09$ & -- & $5.52-10$ \\
\hline $238 U$ & $8.15-05$ & -- & $8.08-07$ & -- & $1.12-07$ \\
\hline${ }^{232} \mathrm{Th}$ & $1.69-02$ & $2.25-02$ & $3.70-03$ & -- & $5.10-04$ \\
\hline Oxygen & $4.56-02$ & $4.50-02$ & $7,50-03$ & -- & $1.04-03$ \\
\hline Nitrogen (a) & -- & $\therefore-$ & $2.49-05$ & $1.48-05$ & $1.61-05$ \\
\hline Carbon & -- & -- & $3.87-02$ & $8.00-02$ & $7.43-02$ \\
\hline
\end{tabular}

(a) At $296 \mathrm{~K}$. For other temperatures, $N_{n}(T)=N_{n}(296) \frac{296}{T(K)}$.

$C / T h=146, C / 233 U=9460$. (HTLTR Lattice 5)

Fuel rod radius $=9.982 \mathrm{~mm}$.

Square lattice pitch $=47.63 \mathrm{~mm}$.

$\mathrm{UO}_{2}-\mathrm{ThO}_{2}$ particle diameter $=0.300 \mathrm{~mm}$.

Distribution of Th0 2 Particle Sizes

\section{Particle Diameter \\ Range (um)}

$0-44$

$44-74$

$74-105$

$105-149$

$149-210$

$>210$
Average Particle

Diameter (mm)

0.022

0.059

0.0895

0.127

0.1795

0.250
Weight

Percent

17.6

32.2

14.4

17.2

14.2

4.4 
TEMPERATURE.DEPENDENT $k_{\infty}$ CORRELATIONS

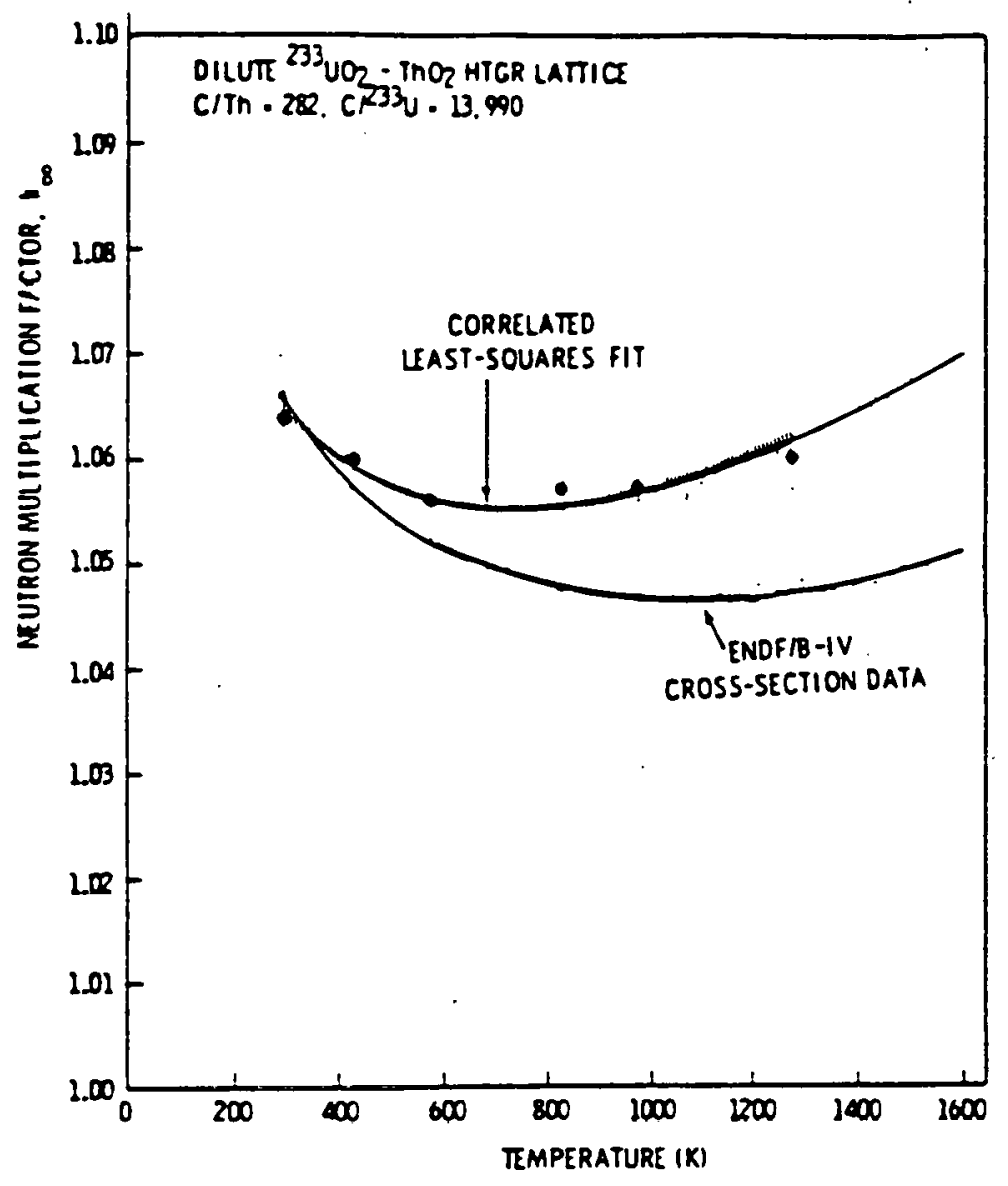

FIGURE 11. Comparison of Calculated and Measured $k_{\infty}(T)$ Values for HTLTR Lattice 3 
TEMPERATURE-DEPENDENT $K_{\infty}$ CORRELATIONS:
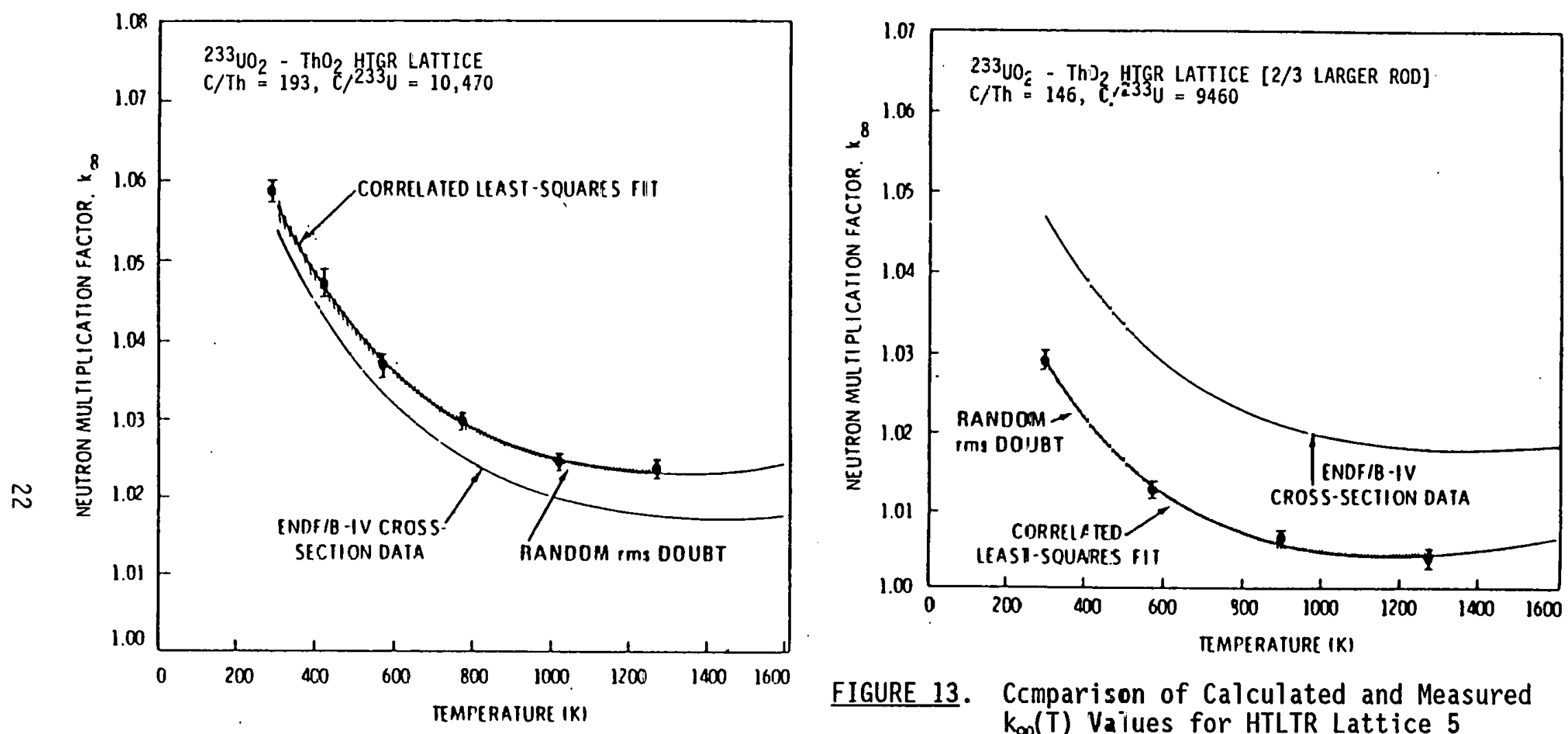

FIGURE 13. Ccmparison of Calculated and Measured $k_{\infty o}(T)$ Vailues for HTLTR Lattice 5

FIGURE 12. Comparison of Calculated and Measured Neutron Multiplication Factors as a Function of Temperature for HTLTR Lattice 2 
TABLE 6. Experimentatal and Calculated $k_{\infty}(T)$ Values for a Dilute $233 \mathrm{UO}_{2}-\mathrm{ThO}_{2}$ HTGR Lattice

$\left[\mathrm{C} / \mathrm{Th}=282, \mathrm{C} / \mathrm{233}^{\mathrm{U}} \mathrm{U}=13,990(\right.$ HTLTR Lattice 3$) ;$ GRANIT/EGGNIT calculations $(8)$ used ENDF/B-IV cross-section data]

\begin{tabular}{|c|c|c|c|}
\hline \multirow[b]{2}{*}{$\begin{array}{c}\text { Temperature } \\
\text { (K) }\end{array}$} & \multicolumn{2}{|c|}{ Experimental Values } & $\begin{array}{c}\text { Calculated } \\
\text { Values }\end{array}$ \\
\hline & $\begin{array}{c}\text { Measured } \\
k_{\infty} \\
\end{array}$ & $\begin{array}{c}\text { Best Theory } \\
\text { Least-Squares-Fit } \\
\text { to Measured Data } \\
k_{\infty} \\
\end{array}$ & $\begin{array}{l}\text { All Data from } \\
\text { ENDF/B-IV } \\
k_{\infty} \\
\end{array}$ \\
\hline 293 & $1.064 \pm 0.004$ & $1.0656 \pm 0.0011$ & 1.0657 \\
\hline 423 & $1.060 \pm 0.006$ & $1.0592 \pm 0.0008$ & 1.0573 \\
\hline 573 & $1.056 \pm 0.005$ & $1.0560 \pm 0.0006$ & 1.0520 \\
\hline 823 & $1.057 \pm 0.005$ & $1.0553 \pm 0.0007$ & 1.0475 \\
\hline 973 & $1.057 \pm 0.006$ & $1.0566 \pm 0.0009$ & 1.0465 \\
\hline 1273 & $1.060 \pm 0.007$ & $1.0615 \pm 0.0012$ & 1.0471 \\
\hline 1600 & -- & -- & 1.0509 \\
\hline
\end{tabular}

TABLE 7. Experimental and Calculated $k_{\infty}(T)$ Values for a $233 \mathrm{UO}_{2}-\mathrm{ThO}_{2} \mathrm{HTGR}$ Lattice

$[C / T h=193, C / 233 \mathrm{U}=10,470($ HTLTR Lattice 2); GRANIT/EGGNIT calculations $(8)$ used ENDF/B-IV cross-section data]

\begin{tabular}{|c|c|c|c|}
\hline \multirow[b]{2}{*}{$\begin{array}{c}\text { Temperature } \\
(\mathrm{K})\end{array}$} & \multicolumn{2}{|c|}{ Experimental Values } & $\begin{array}{c}\text { Calculated } \\
\text { Values }\end{array}$ \\
\hline & $\begin{array}{c}\text { Measured } \\
k_{\infty}\end{array}$ & $\begin{array}{c}\text { Best Theory } \\
\text { Least-Squares-Fit } \\
\text { to Measured Data } \\
k_{\infty} \\
\end{array}$ & $\begin{array}{c}\text { A1 1 Data from } \\
\text { ENDF/B-IV } \\
k_{\infty} \\
\end{array}$ \\
\hline 293 & $1.0587 \pm 0.0014$ & $1.0580 \pm 0.0004$ & 1.0544 \\
\hline 423 & $1.0471 \pm 0.0017$ & $1.0473 \pm 0.0004$ & 1.0428 \\
\hline 573 & $1.0367 \pm 0.0014$ & $1.0376 \pm 0.0003$ & 1.0334 \\
\hline 773 & $1.0297 \pm 0.0011$ & $1.0295 \pm 0.0002$ & 1.0251 \\
\hline 1023 & $1.0245 \pm 0.0011$ & $1.0248 \pm 0.0003$ & 1.0199 \\
\hline 1273 & $1.0237 \pm 0.0012$ & $1.0233 \pm 0.0004$ & 1.0176 \\
\hline 1600 & -- & -- & 1.0177 \\
\hline
\end{tabular}


TABLE 8. Experimental and Calculated $k_{\infty}(T)$ Values for a $233 \mathrm{UO}_{2}-\mathrm{ThO}_{2}$ HTGR Lattice (2/3 larger fuel rod)

$[\mathrm{C} / \mathrm{Th}=146, \delta / 233 \mathrm{U}=9460$ (HTLTR Lattice 5); GRANIT/EGGNIT calculations $(8)$ used ENDF/B-IV cross-section data]

\begin{tabular}{|c|c|c|c|}
\hline \multirow[b]{2}{*}{$\begin{array}{l}\text { Temperature } \\
(\mathrm{K})\end{array}$} & \multicolumn{2}{|c|}{ Experimental Values } & $\begin{array}{c}\text { Calculated } \\
\text { Values }\end{array}$ \\
\hline & $\begin{array}{c}\text { Measured } \\
k_{\infty}\end{array}$ & $\begin{array}{c}\text { Best Theory } \\
\text { Least-Squares-Fit } \\
\text { to Measured Data } \\
k_{\infty} \\
\end{array}$ & $\begin{array}{c}\text { A11 Data from } \\
\text { ENDF/B-IV } \\
k_{\infty} \\
\end{array}$ \\
\hline 293 & $1.0291 \pm 0.0012$ & $1.0291 \pm 0.0005$ & 1.0473 \\
\hline 573 & $1.0127 \pm 0.0010$ & $1.0130 \pm 0.0004$ & 1.0301 \\
\hline 900 & $1.0065 \pm 0.0010$ & $1.0058 \pm 0.0003$ & 1.0211 \\
\hline 1273 & $1.0037 \pm 0.0012$ & $1.0043 \pm 0.0006$ & 1.0179 \\
\hline 1600 & -.. & -.. & 1.0186 \\
\hline
\end{tabular}

Compositions for the $\mathrm{PuO}_{2}-\mathrm{ThO}_{2}$ HTGR lattice(12) are listed in Table 9; the $\mathrm{C} / \mathrm{Th}$ atom ratio is about 250 and the $\mathrm{C} / \mathrm{Pu}$ atom ratio is about 7500 . Similar fuel containing $\mathrm{PuO}_{2}$ microspheres and graphite in the fuel rod region, but with $\mathrm{V}_{2} \mathrm{O}_{3}$ in $\mathrm{place}$ of $\mathrm{ThO}_{2}$ particles, was used to measure the temperature-dependent $k_{\infty}$ of this HTGR lattice with the thorium resonance capture removed. (13) The $1 / v$ absorption cross section of vanadium in 273 grams of $\mathrm{V}_{2} \mathrm{O}_{3}$ just compensates for the $1 / v$ portion of the absorption cross section of thorium in 657 grams of $\mathrm{ThO}_{2}$ that it replaces in each fuel block. Results of comparisons of experimental and calculated $k_{\infty}$ values for the $\mathrm{PuO}_{2}-\mathrm{ThO}_{2}$ HTGR lattice and the $\mathrm{PuO}_{2}-\mathrm{V}_{2} \mathrm{O}_{3}$ HTGR lattice are shown in Figure 14. Numerical comparisons for the $\mathrm{PuO}_{2}-\mathrm{ThO}_{2}$ HTGR lattice are listed in Table 10.

Similar measurements were made in the HTLTR with a $23 \mathrm{UC}_{2}-\mathrm{V}_{2} \mathrm{O}_{3} \mathrm{HTGR}$ lattice. (14) The $1 / v$ absorption cross section of vanadium in 362 grams of $\mathrm{V}_{2} \mathrm{O}_{3}$ just compensates for the $1 / v$ portion of thorium in $871 \mathrm{grams}$ of $\mathrm{ThO}_{2}$ that it replaces in a $235 \mathrm{UC}_{2}-\mathrm{ThO}_{2} \mathrm{HTGR}$ lattice block. Comparison of the $k_{\omega}(T)$ behavior for the $235 \mathrm{UC}_{2}-\mathrm{V}_{2} \mathrm{O}_{3}$ and $235 \mathrm{UC}_{2}-\mathrm{ThO}_{2}$ HTGR lattices is shown in Figure 15. At temperatures up to $580 \mathrm{~K}$, the temperature coefficient of reactivity for the $235 \mathrm{UC}_{2}$ HTGR lattice (without thorium) is essentially zero. 
TABLE 9. Composition of $\mathrm{PuO}_{2}-\mathrm{ThO}_{2}$ HTGR Lattice

\begin{tabular}{|c|c|c|c|c|c|}
\hline Nucl ide & $\begin{array}{l}\mathrm{PuO}_{2} \\
\text { Particles }\end{array}$ & $\begin{array}{l}\mathrm{ThO}_{2} \\
\text { Particles }\end{array}$ & $\begin{array}{l}\text { Fuel Rod } \\
\text { Region }\end{array}$ & $\begin{array}{l}\text { Moderator } \\
\text { Region }\end{array}$ & $\begin{array}{l}\text { Homogenized } \\
\text { Cell Average }\end{array}$ \\
\hline 238pu & $1.65-05$ & -- & $2.00-08$ & -- & $6.17-09$ \\
\hline${ }^{239} \mathrm{pu}$ & $1.84-02$ & -- & $2.23-05$ & -- & $6.88-06$ \\
\hline${ }^{240} \mathrm{Pu}$ & $5.79-03$ & $\because$ & $7.00-06$ & -- & $2.16-06$ \\
\hline${ }^{241} \mathrm{Pu}$ & $8.35-04$ & -- & $1.01-06$ & -- & $3.12-07$ \\
\hline${ }^{242} \mathrm{pu}$ & $2.32-04$ & $\therefore$ & $2.80-07$ & -- & $8.64-08$ \\
\hline${ }^{244} \mathrm{Pu}$ & $2.48-07$ & -- & $3.00-10$ & -- & $9.25-11$ \\
\hline $241_{A m}$ & 4.96-05 & -- & $6.00-08$ & - & $1.85-08$ \\
\hline${ }^{232} \mathrm{Th}$ & -- & $2.28-02$ & $9.17-04$ & -- & $2.83-04$ \\
\hline Oxygen & 5.04-02 & 4.56-02 & $1.90-03$ & -- & $5.86-04$ \\
\hline Nitrogen $(a)$ & -. & -- & $2.73-05$ & $1.43-05$ & $1.83-05$ \\
\hline Carbon & -- & $\therefore$ & $4.78-02$ & $8.14-02$ & $7.10-02$ \\
\hline
\end{tabular}

(a) At $296 \mathrm{~K}$. For other temperatures, $N_{n}(T)=N_{n}(296) \frac{296}{T(K)}$.

$\mathrm{C} / \mathrm{Th}=251.6, \mathrm{C} / \mathrm{Pu}=7541 . \quad($ HTLTR Lattice 4$)$

Fue $]$ rod radius $=5.969 \mathrm{~mm}$.

Square lattice pitch $=19.05 \mathrm{~mm}$.

$\mathrm{PuO}_{2}$ particle diameter $=0.209 \mathrm{~mm}$.

Thoria Particle Size Distribution

\begin{tabular}{cccc}
\hline $\begin{array}{c}\text { Tyler } \\
\begin{array}{c}\text { Standard } \\
\text { Screen Mesh }\end{array}\end{array}$ & $\begin{array}{c}\text { Particle Size } \\
\text { Range } \\
(\mu \mathrm{m})\end{array}$ & $\begin{array}{c}\text { Average Particle } \\
\text { Size } \\
(\mu \mathrm{m})\end{array}$ & \\
\cline { 2 - 3 } $100-65$ & $149-210$ & 180 & wt\% \\
$150-100$ & $105-149$ & 127 & 11.1 \\
$200-150$ & $74-105$ & 90 & 16.3 \\
$325-200$ & $44-74$ & 59 & 13.7 \\
$>325$ & $0-44$ & 22 & 18.8 \\
& & & 40.1
\end{tabular}




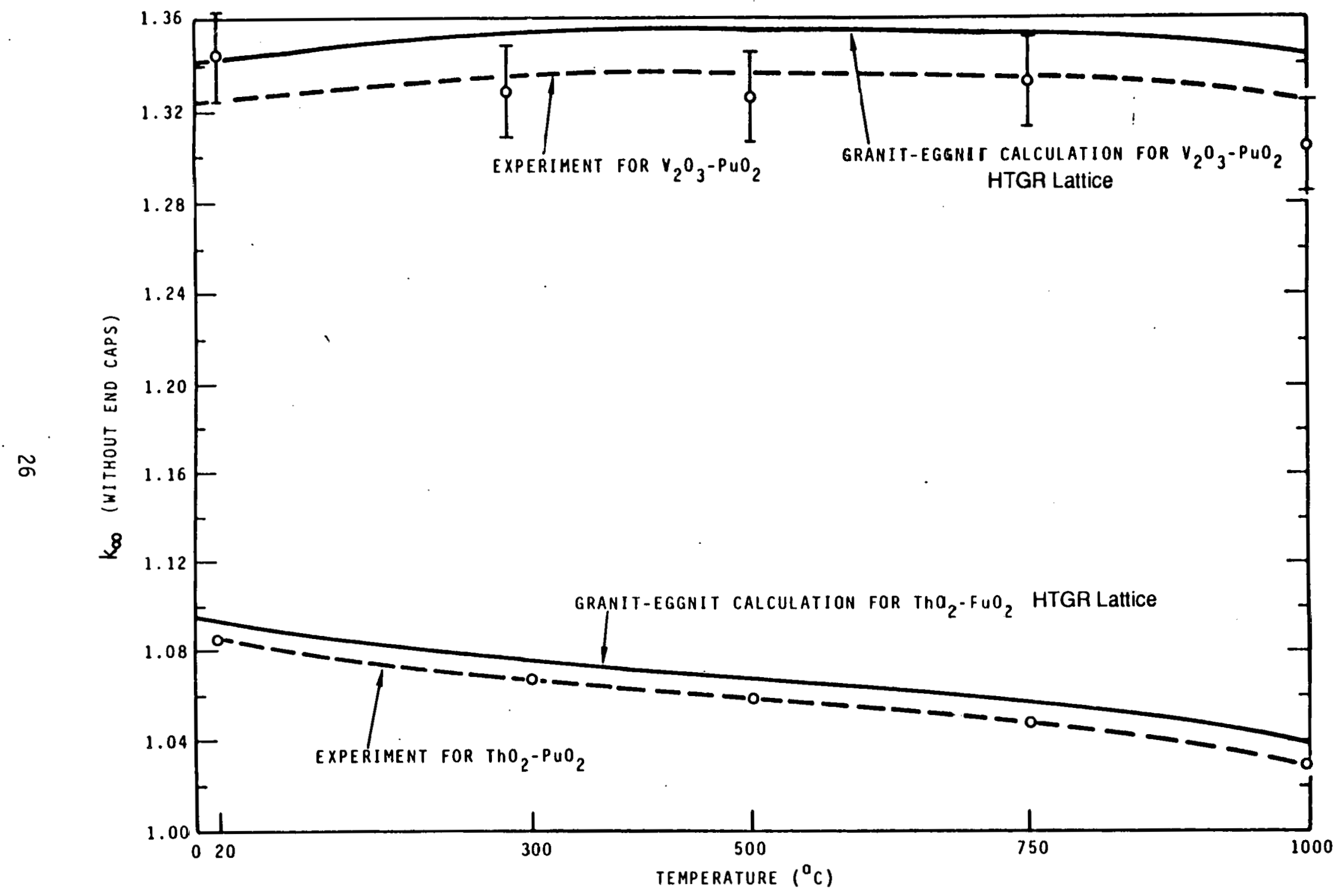

FIGURE 14. Comparison of Calculated and Measured Values of $\mathrm{k}_{\infty}$ for $\mathrm{V}_{2} \mathrm{O}_{3}-\mathrm{PuO}_{2}$ and $\mathrm{ThO}_{2}-\mathrm{PuO}_{2}$ HTGR Lattices 
TABLE 10. Experimental and Calculated $k_{\infty}(T)$ Values for a $\mathrm{PuO}_{2}-\mathrm{ThO}_{2}$ HTGR Lattice

$[\mathrm{C} / \mathrm{Th}=251.6, \mathrm{C} / \mathrm{Pu}=7541$ (HTLTR Lattice 4); GRANIT/EGGNIT calculations(13) used ENDF/B-III cross section data]

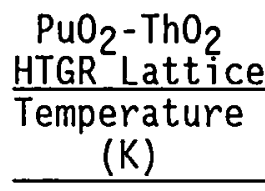

293

573

773

1023

1273
Experimental Values

Best Theory Least-Squares-Fit

Measured

$k_{\infty}$

$1.085 \pm 0.003$

$1.067 \pm 0.003$

$1.059 \pm 0.003$

$1.048 \pm 0.002$

$1.029 \pm 0.002$ to Measured Data $\left(k_{\infty}\right)$

$1.085 \pm 0.001$

$1.068 \pm 0.001$

$1.060 \pm 0.001$

$1.047 \pm 0.001$

$1.029 \pm 0.001$

Calculated

values

A11 Data from ENDF/B-III $\left(k_{\infty}\right)$

1.092

1.076

1.068

1.056

1.039

Analyses of HTLTR reactivity measurements for the $235 \mathrm{UC}_{2}-\mathrm{V}_{2} \mathrm{O}_{3}$ HTGR lattice between $580 \mathrm{~K}$ and $1273 \mathrm{~K}$ were not completed, but the measured data continues the trend established below $580 \mathrm{~K}$. 


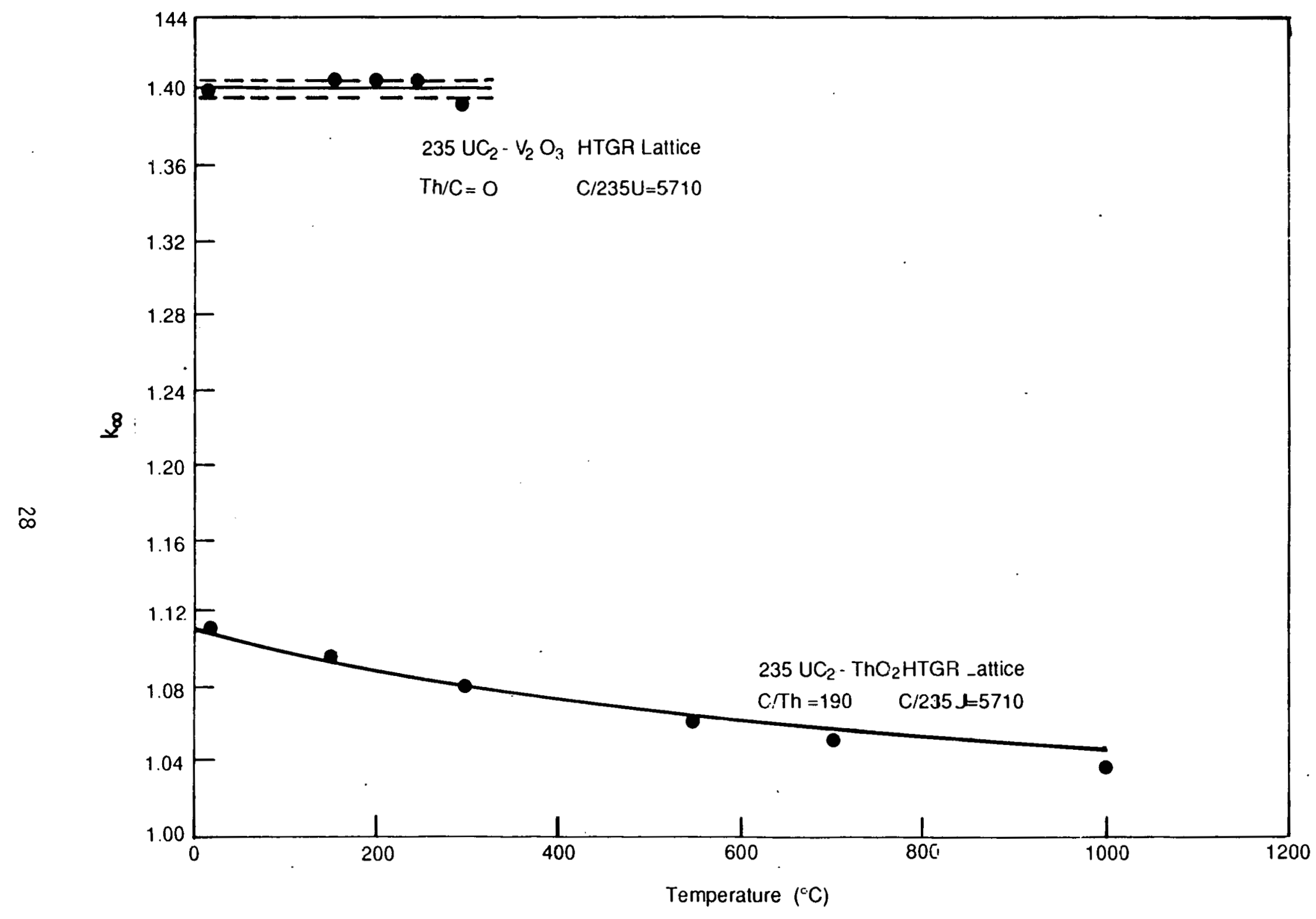

FIGURE 15. Comparison of $k_{\infty}(T)$ for $235 \mathrm{UC}_{2}-\mathrm{V}_{2} \mathrm{O}_{3}$ and $235 \mathrm{UC} \mathrm{C}_{2}-\mathrm{ThO}_{2}$ HTGR Lattices 


\section{CORRECTIONS OF CALCULATIONAL BIAS}

The neutron multiplication factors calculated as a function of temperature, $k_{\infty}(T)$, for all HTGR lattices tested in the HTLTR, and described in the previous section, have been normalized and rotated to fit the measured values(15) for each experiment by use of the equation

$$
\text { Measured }_{k_{\infty}(T)}=\text { Calculated }_{k_{\infty}(T)}[A+B(T-293 K)]^{\prime}
$$

The correlation coefficients $A$ and $B$ were determined by a least-squaresfitting procedure using the LEARN computer code. (16) The fitting procedure was performed for results calculated for each different HTGR lattice $k_{\infty}(T)$ data to determine the effects of the fuel block composition on calculational bias.

Measured and calculated temperature coefficients are related by the equation

$$
\operatorname{Meas}\left(\frac{1}{k_{\infty}} \frac{d k_{\infty}}{d T}\right)=\operatorname{Calc}\left(\frac{1}{k_{\infty}} \frac{d k_{\infty}}{d T}\right)+\frac{B}{A+B(T-293 K)}
$$

In all cases, the value of the correction term is essentially the value of the coefficient $B$. This is because the order of $A$ is unity, the order of $B$ is $10^{-5}$, and $T$ ranges from 293 to $1273 \mathrm{~K}\left(20\right.$ to $\left.1000^{\circ} \mathrm{C}\right)$. Thus, the value of B provides an estimate of the bias correction for calculated temperature coefficients.

The correlation procedure using Eq. (3) was chosen because it minimizes the number of free-fitting parameters, it retains the physical significance of the temperature-dependent shape of the calculations, and because the result fit the measured data well within the estimate of measurement error. Minimization of the number of free parameters is important for reducing the chance of introducing artifacts into the correlation, since there are only six measured values of the $k_{\infty}$ in the range from 293 to $1273 \mathrm{~K}\left(20\right.$ to $\left.1000^{\circ} \mathrm{C}\right)$ for three of the HTGR experimental lattices. The $\mathrm{PuO}_{2}-\mathrm{ThO}_{2} \mathrm{HTGR}$ experimental 
lattice had five measured values of the $\mathrm{k}_{\infty}(T)$ and the $233 \mathrm{UO}_{2}-\mathrm{ThO}_{2}$ HTGR lattice with a larger fuel rod had only four measured values of $k_{\infty}(T)$.

The LEARN program, which was used to fit the coefficients $A$ and $B$ of Eq. (3), calculates the value of chi-squared per degree of freedom from the least-squares fit. This value should be unity if the original random error estimates in the measured data are correct. Since the value of $x^{2} / \eta$ was only - 0.3 for each of the experiments, we can conclude that the original random error estimates were pessimistic.

The correlated least-squares-fit curves to the measured data for $k_{\infty}(T)$, and the random root-mean-square doubt intervals from the LEARN statistical analysis are shown in rigures 10 through 14 for the five HTGR-fueled HTLTR lattices. Equal weighing of the measured data was used in the leastsquares-fitting procedure for HTLTR lattice 3 since the quoted uncertainties in the measured data are dominated by nonuniform systematic error estimates rather than random error estimates (which the least-squares analysis indicates are much smaller than the quoted uncertainty estimates).

The correlation coefficient A of Eq. (3) corresponds to the ratio of the measured-to-calculated values for $k_{\infty}$ at room temperature and is thus a normalizing coefficient. The coefficient $B$ expresses the bias in the calculated temperature coefficient of reactivity. The values obtained for the correlation coefficients $A$ and $B$ from calculations for each of the HTGR lattices tested in the HTLTR are compared in Table 11. The values of coefficient $B$ obtained from all three $233 \mathrm{UO}_{2}-\mathrm{ThO}_{2}$ lattices, indicate that the calculated values of $\left(1 / k_{\infty}\right)\left(d k_{\infty} d d T\right)$ are more negative than the measurements. Although these calculations are nonconservative, the magnitude of the bias is relatively smal1.(15)

The values of the coefficient $\mathrm{B}$ obtained for the $\mathrm{PuO}_{2}-\mathrm{ThO}_{2}$ and the $235 \mathrm{UC}_{2}-\mathrm{ThO}_{2}$ are slightly negative, indicating that the calculated temperature coefficient of reactivity is conservative. However, when the thorium is removed, as in the $\mathrm{PuO}_{2}-\mathrm{V}_{2} \mathrm{O}_{3}$ HTGR lattice, the calculation becomes nonconservative. The trends of the correction to calculated temperature coefficients of reactivity as thorium is removed from the HTGR lattices is shown in Figure 16. For all fissile fuels, the value of $B$ becomes positive when 
TABLE 11. Comparison of Least-Squares Correlation Coefficients for $k_{\infty}(T)$ Values Calculated for Each HTGR Lattice Tested in the HTLTR

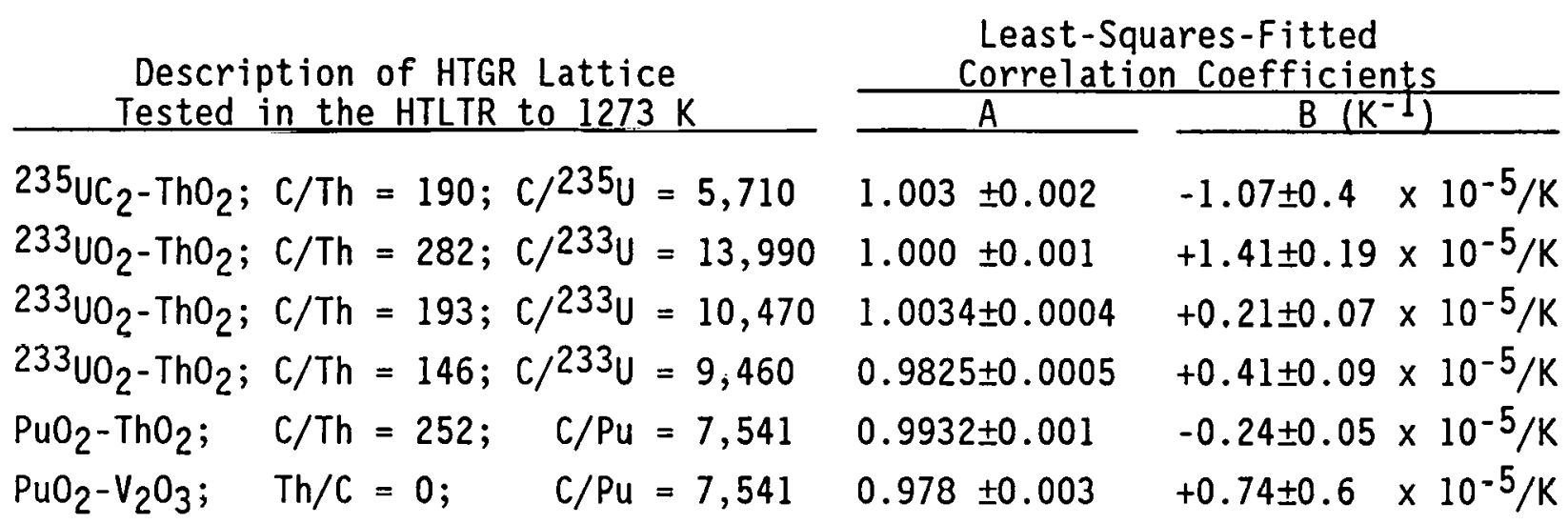

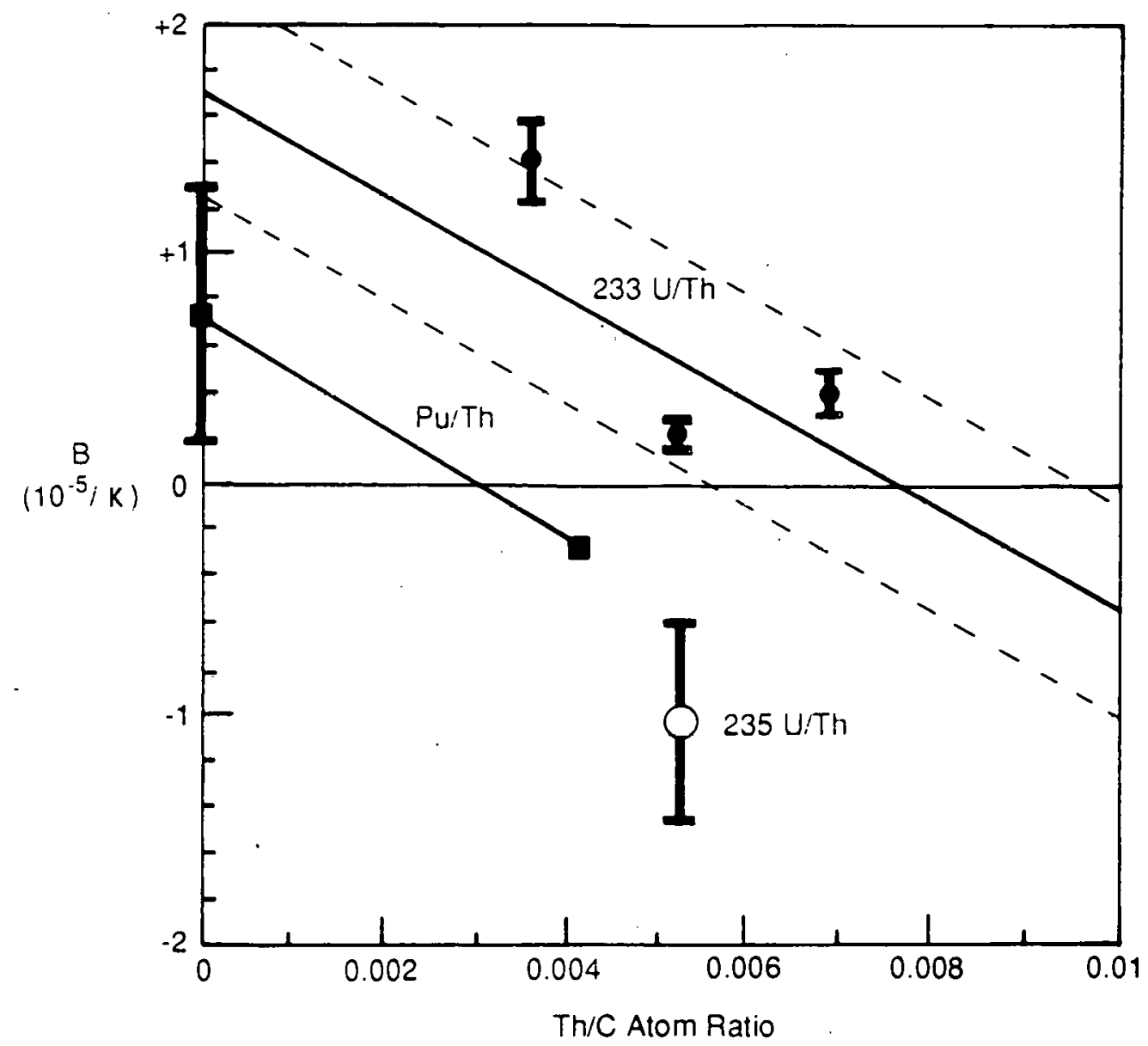

FIGURE 16. Correction of Temperature Coefficient of Reactivity Calculated for HTGR Lattices Using ENDF/B-IV Cross Section Data 
thorium is absent from the fuel. As a result, the calculated temperature coefficients for HTGR lattices without significant fertile material (Th or $238 \mathrm{U}$ ) are expected to be nonconservative by 1 to $2 \times \cdot 10^{-5} / \mathrm{K}$. 


\section{CONCLUSIONS}

The values of $k_{\infty}(T)$ measured in the HTLTR for five HTGR test cores provide a consistent set of benchmark data that can be used to validate unit cell calculations of doubly heterogeneous HTGR lattices. The neutron spectrum averaged self-shielding effects of both the fissile and fertile fuel particles, as well as thermal neutron spectrum variations in the fuel rod surrounded by graphite moderator, and the rod-to-rod resonance shielding effects must be accurately accounted for in calculations to be compared with the HTGR lattice measurements. Unit cell calculations must be made using the fundamental mode neutron spectrum generated in a just critical bare array of the test material, to be consistent with the measurement conditions. Such

PNL calculations made with GRANIT/EGGNIT using ENDF/B-IV cross-section data for comparison to the measured $k_{\infty}(T)$ values show that:

- Absolute values of $k_{\infty}$ can be calculated within about $1 \%$ of the measured values at room temperature.

- The differences between calculated and measured values of $k_{\infty}$ are larger than can be accounted for by the $1 \%$ uncertainty in the fissile content of the coated microspheres.

- Calculated values of $k_{\infty}$ for the most heterogeneous lattice (HTLTR Lattice 5) are nearly $2 \%$ higher than measured values, indicating overestimation of resonance shielding and/or underestimation of thermal flux depression in the fuel region. This lattice is more sensitive to the latter effect.

- The HTLTR data provides accurate benchmarks for determining the magnitude of bias in calculated temperature coefficients of reactivity for HTGR lattices.

- Calculatjons of temperature coefficients of reactivity for all three $233 \mathrm{U}$ fueled HTGR lattices were non-conservative (more negative than measured).

- The trend, as thorium was removed from HTGR lattices, was to calculate temperature coefficients that were more non-conservative.

- The non-conservative bias in calculated temperature coefficients of reactivity for HTGR lattices tested in the HTLTR was 1 to $2 \times 10^{-5} / \mathrm{K}$ when thorium was not present. 
In order to increase measurement accuracy by keeping $k_{\infty}$ less than 1.1 , the HTLTR experiments used HTGR fuel loadings that contained only about one-half to one-third of the fissile fuel concentration in typical fresh commercial HTGR cores such as that shown in Figure 2. Increased fissile fuel concentrations may amplify calculational errors in underestimation of thermal flux depression in the fuel region and lead to larger errors in calculation of $k_{\infty}(T)$ than indicated by comparisons, to HTLTR measurements. Measurements on a $235 \mathrm{UC}_{2}$-fueled HTGR lattice (without thorium) in the HTLTR (shown in Figure 15) indicate that the temperature coefficient of reactivity for such compositions is essentially zero. A $1 / \mathrm{v}$. neutron absorber $\left(\mathrm{V}_{2} \mathrm{O}_{3}\right)$ was present in the fuel in a concentration that provided a $1 / v$ neutron cross section equivalent to the thorium it displaced. The effect of lumped $1 / v$ neutron absorbers outside the HTGR unit cell, such as boron control rods used in FSV, on the temperature coefficient of reactivity may be negative since therma? neutron self-shielding effects are reduced as temperature increases. However, the reactivity feedback from such isolated absorbers may not provide the prompt reactivity feedback necessary for HTGR power stability and transient response due to the time lag for heat transfer from the fuel to the absorber. 


\section{REFERENCES}

1. Dahtberg, R. C., R. F. Turner, and W. V. Goeddel. 1974. "HTGR Fuel and Fuel Cycle Summary Description." GA-A12801, Rev., General Atomic Company, LaJolla, Cal ifornia.

2. Holmes, J. A. G. 1961. "Specification for HERO--A Low Power High Temperature Experimental Reactor." DEG-345(R), U. K. Atomic Energy Authority, Risley.

3. Department Des Etudes De Piles, Commissariat a 1'Energie Atomique. 1961. "Empilement Critique Chaud--CESAR." Rapport DEP No. 13.

4. Reynolds, H. L. and C. E. Walter. 1959. "HOT BOX--A High Temperature Critical Facility." UCRL-5483, Lawrence Livermore Laboratory, Livermore, Cal ifornia.

5. Bennett, C. L. 1971. "GRANIT: A Code for Calculating Position Dependent Thermal Neutron Spectra in Doubly Heterogeneous Systems by the Integral Transport Method." BNWL-1634, Pacific Northwest Laboratory, Richland, Washington.

6. Richey, C. R. 1969. "EGGNIT: A Multigroup Cross Section Code." BNWL-1203, Pacific Northwest Laboratory, Richland, Washington.

7. Richey, C. R. and T. J. Oakes. 1972. "Determination of Neutron Multiplication Factors as a Function of Temperature with the High Temperature Lattice Test Reactor." Nucl. Sci. Eng., 47:40.

8. Newman, D. F., et a7. 1977. "Evaluation of Temperature Coefficients of Reactivity for $233 \mathrm{U}$--Thorium Fueled HTGR Lattices." EPRI NP-222, Electric Power Research Institute, Palo Alto, California.

9. Oakes, T. J 1972. "Measurement of $k_{\infty}$ as a Function of Temperature for a $233 \mathrm{UO}_{2}-232 \mathrm{ThO}_{2}-\mathrm{C}$ Lattice." BNWL-1601, Pacific Northwest Laboratory, Richland, Washington.

10. Lippincott E. P. 1972. "Measurement of the Temperature Dependence of $\mathrm{k}_{\infty}$ for a $233 \mathrm{UO}_{2}$-ThO ${ }_{2}$ High Temperature Gas-Cooled Reactor Lattice." Nucl. Sci. Eng., 47:475.

11. Lippincott, E. P. 1972. "Measurement of Physics Parameters for a MSBR Lattice in the HTLTR." BNWL-1633, Pacific Northwest Laboratory, Richland, Washington.

12. Newman, Darre11 F. 1973. "Temperature-Dependent $\mathrm{k}_{\infty}$ for a $\mathrm{ThO}_{2}-\mathrm{PuO}_{2}$ HTGR Lattice." Nucl. Technol., 19:66. 
13. Newman, Darre11 F. 1972. "Measurement of Neutronic Parameters for a Plutonium Fueled HTGR Lattice." BNWL-1678, Pacific Northwest Laboratory, Richland, Washington.

14. Lanning, D. D. 1969. "High Temperature Reactor Physics Program Status Report." BNWL-CC-2096. Pacific Northwest Laboratory, Richland, Washington.

15. Newman, D. F. and B. F. Gore. 1978. "Neutron Multiplication Factors as a Function of Temperature: A Comparison of Calculated and Measured Values for Lattices Using ${ }^{233} \mathrm{UO}_{2}-\mathrm{ThO}_{2}$ Fuel in Graphite." Nucl. Technol. $37: 227$.

16. Seybold, G. D. 1969. "Users Aid: Programs LEARN and LIKELY." BNWL-1057, Pacific Northwest Laboratory, Richland, Washington.

17. Heineman, R. E. 1965. "On the Interpretation of Reactivity Measurements of Reactor Media." Trans. Am. Nucl. Soc. 8:532.

18. Lippincott, E. P. et al. 1969. "Definition of the Infinite Neutron Multiplication Factors Measured by the PCTR Poisoned and Unpoisoned Technique," Reactor Physics Quarterly Report, July. August, September, BNWL-1240, Pacific Northwest Laboratory, Richland, Washington.

19. Lippincott, E. P. 1971. "Derivation of Corrections of $k_{\infty}$ in the Two-Group Approximation," BNWL-1560, Pacific Northwest Laboratory, Richl and, Washington.

20. Newman, D. F. 1971. "An Improved Method for Calculating Foil Perturbation Effects," Nucl. Sci. Eng., 44:261.

21. Lippincoff $E$. P. 1971. "Measurement of the Temperature Dependence of $\mathrm{k}_{\infty}$ for a $233 \mathrm{UO}_{2}-\mathrm{ThO}_{2}$ HTGR Lattice." BNWL-1561, Pacific Northwest Laboratory, Richland, Washington.

22. Hanthorn, H. E. 1966. "Final Safeguards Analysis: High Temperature Lattice Test Reactor." BNWL-CC-225, Pacific Northwest Laboratory, Richl and, Washington.

23. Little, W. W. and Hardie, R. W. 1969. "2DB Users ManauT - Revision 1." BNWL-831, Pacific Northwest Laboratory, Richland, Washington. 
APPENDIX A

PRINCIPLE OF THE MEASUREMENTS

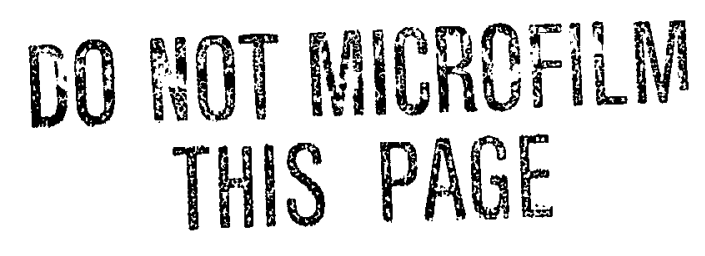




\section{PRINCIPLE OF THE MEASUREMENTS}

The primary neutronic characteristic of a test lattice that is measured in the High Temperature Lattice Test Reactor (HTLTR), shown in Figure 1, is the infinite medium neutron multiplication factor, $k_{\infty}$, as a function of temperature. (7)

The measured quantity is not for a true infinite medium, but rather for a bare critical reactor. Thus, $k_{\infty}$ is evaluated for neutron flux spectra in the fundamental mode. To avoid ambiguity, $k_{\infty}$ is defined by

$$
k_{\infty}=\frac{\text { total production }}{\text { total absorption }}
$$

This quantity can be calculated directly for comparison to measured quantities using multigroup cell codes.

$$
k_{\infty}=\sum_{i=1}^{n}\left(\nu_{i} \Sigma_{f_{i}} \phi_{i}\right) / \sum_{i=1}^{n}\left(\Sigma_{a_{i}} \phi_{i}\right)
$$

where $\phi_{j}=i^{\prime}$ th group neutron flux at the center of a just critical bare assembly of the test lattice, and $\nu_{j} \Sigma_{\mathrm{f}}$ and $\Sigma_{\mathrm{a}}$ are cell-averaged macroscopic neutron production and absorption cross sections, respectively, in the $i$ 'th energy group.

For simplicity these fundamental mode spectrum averaged cross sections can be collapsed into two energy regions, and the expression becomes. (a)

(a) $k_{\infty}$ as defined in this paper is equivalent to $k_{\infty}^{\dagger}$ as defined in reference 7 and $k_{\infty}^{\prime}$ as defined in reference 18. The fluxes, $\phi_{1}, \phi_{2}$, in this paper are equivalent to $\phi\{, \phi$ as defined in references 7 and 18 . The primes have been deleted herein for simplicity of notation. 


$$
\mathrm{k}_{\infty}=\frac{\nu_{1} \Sigma_{1}^{\mathrm{f}} \phi_{1}+\nu_{2} \Sigma_{2}^{\mathrm{f}} \phi_{2}}{\Sigma_{1}^{\mathrm{a}} \phi_{1}+\Sigma_{2}^{\mathrm{a}} \phi_{2}}
$$

where subscript 2 represents the thermal region and subscript 1 represents the epithermal region. These quantities are also related by the two-group equations

$$
\begin{aligned}
& -\mathrm{D}_{1} \mathrm{~B}^{2} \phi_{1}-\Sigma_{1}^{\mathrm{a}} \phi_{1}-\Sigma_{12} \phi_{1}+\nu \Sigma_{1}^{\mathrm{f}} \phi_{1}+\nu \Sigma_{2}^{\mathrm{f}} \phi_{2}=0 \\
& -\mathrm{D}_{2} \mathrm{~B}^{2} \phi_{2}-\Sigma_{2}^{\mathrm{a}} \phi_{2}+\Sigma_{12} \phi_{1}=0,
\end{aligned}
$$

where $\Sigma_{12}$ is the cross section for transfer from group 1 to group 2 and $B^{2}$ is the material buckling.

The fundamental mode neutron fluxes in Eq. (A.4) can be eliminated by defining the following lattice parameters:

$$
\begin{aligned}
& \tau=\frac{D_{1}}{\Sigma_{1}^{\mathrm{a}}+\Sigma_{1 \rightarrow 2}} \\
& L^{2}=\frac{D_{2}}{\Sigma_{2}^{\mathrm{a}}} \\
& \eta_{1} f_{1}=\frac{\nu \Sigma_{1}^{f}}{\Sigma_{1}^{\mathrm{a}}}, \eta_{2} \mathrm{f}_{2}=\frac{\nu \Sigma_{2}^{f}}{\Sigma_{2}^{\mathrm{a}}} \\
& \mathrm{p}=\frac{\Sigma_{1 \rightarrow 2}}{\Sigma_{1 \rightarrow 2}+\Sigma_{1}^{\mathrm{a}}}
\end{aligned}
$$

Substituting these terms into Eqs. (A.3) and (A.4) gives 


$$
k_{\infty}=\frac{\eta_{1} f_{1}(1-p)\left(1+L^{2} B^{2}\right)+\eta_{2} f_{2} p}{1+(1-p) L^{2} B^{2}}
$$

where, $\mathrm{B}^{2}$ is the material buckling of the test lattice which is equivalent to the fundamental mode (geometric) buckling for a just critical array of the test lattice.

$$
k_{e f f}=1=\frac{k_{\infty}\left[1+(1-p) L^{2} B^{2}\right]}{\left(1+\tau B^{2}\right)\left(1+L^{2} B^{2}\right)}
$$

A rearrangement of Eq. (A.10) illustrates the relationship between $k_{\infty}$ and the fundamental mode buckling, $B^{2}$.

$$
k_{\infty}=\frac{\left(1+\tau B^{2}\right)\left(1+L^{2} B^{2}\right)}{1+(1-p) L^{2} B^{2}} .
$$

The excess neutron production in the test lattice, $k_{\infty}-1$, is determined from the ratio of reactivity perturbations of a test lattice sample and a normalizing neutron absorber, using the unpoisoned technique.(17) A small sample of the test lattice (referred to as the central cell) is inserted to fill the void in the center of the HTLTR. Surrounding this void is a region of test lattice identical to the central cell, and the neutron spectrum in this region is adjusted to be as close as possible to the fundamental mode conditiun. (18) The reactivity perturbation caused by insertion of the central cell is normalized to the perturbation produced when a sample of copper is placed in the central void of the HTLTR.

Using first order perturbation theory and the fundamental mode neutron spectrum collapsed to two-energy-groups, the relationship between $k_{\infty}$ and the measured quantities can be derived: $(18,19)$ 


$$
\begin{aligned}
& k_{\infty}=1-\left(\frac{\Delta \rho^{\mathrm{Ce} I 1}}{\Delta \rho \mathrm{Cu}}\right) \frac{\left(\Sigma_{a} \phi V\right)_{2}^{C u}}{\left(\Sigma_{a} \phi V\right)_{2}^{C e l 1}}\left[1+\left[\frac{\phi_{1}^{\dagger}}{\phi_{2}^{\dagger}}\right] \frac{\left(\Sigma_{a} \phi\right)_{1}^{C u}}{\left(\Sigma_{a} \phi\right)_{2}^{C u}}\right] \\
& -\frac{\left(1+\tau B^{2}\right)\left(1+L^{2} B^{2}\right)(1-p) L^{2} B^{2}}{1+(1-p) L^{2} B^{2}}+\frac{\tau B^{2}\left(1+L^{2} B^{2}\right)\left[\tau B^{2}-\eta_{1} f_{1}(1-p)\right]}{1+\tau B^{2}-\eta_{1} f_{1}(1-p)} \\
& -\frac{\left(\tau B^{2}\left(1+L^{2} B^{2}\right)\right.}{1+\tau B^{2}-\eta_{1} f_{1}(1-p)}\left[\frac{\Delta \Phi}{\Phi}+\frac{\Delta \Phi^{\dagger}}{\Phi^{\dagger}}\right) \\
& +\frac{\left(1+L^{2} B^{2}\right)\left[1-\eta_{1} f_{1}(1-p)\right]}{1+\tau B^{2}-\eta_{1} f_{1}(1-p)}\left[\frac{\Delta \Phi}{\Phi} \frac{\Delta \Phi^{\dagger}}{\Phi^{\dagger}}\right)
\end{aligned}
$$

In Eq. (A.12), $\Delta \rho^{\mathrm{Ce}} 11$ and $\Delta \rho^{\mathrm{Cu}}$ represent the reactivity changes due to insertion of the central cell or copper into the void, respectively; $\left(\Sigma_{2}^{\mathrm{a}} V_{\phi_{2}}\right)$ cell represents the actual thermal-neutron absorption rate in the central ce11; $\left(\Sigma_{2}^{\mathrm{a}} \mathrm{V}_{2}\right)^{\mathrm{Cu}}$ represents the actual thermal-neutron absorption rate in the copper; and $\left(\Sigma_{a} \phi\right)_{1}^{C u} /\left(\Sigma_{a} \phi\right)_{2}^{C u}$ represents the ratio of epithermal-tothermal absorption rates in the copper placed in the central HTLTR void. Neutron absorption rates in the central cell constituents and the copper were measured by foil activation methods, and corrected for foil perturbation effects. (20)

The first term in this expression is the preponderant term for thermal spectrum test lattices, and is evaluated experimentally. The next two terms are small calculated corrections which account for fundamental mode neutron leakage effects from the central cell. The last two terms in Eq. (A.12) are calculated two-group corrections for neutron spectrum mismatch from fundamental mode values, where $\Phi$ is defined as $\phi_{1} / \phi_{2}$ and $\Delta \Phi$ is the difference between $\Phi$ for the fundamental mode and the $\Phi$ actually present with the central cell inserted; $\Phi^{\dagger}$ is defined similarly for the adjoint fluxes except $\Delta \Phi^{\dagger}$ is evaluated at the surface of the void. 
Since the fundamental mode buckling, $B^{2}$, is not measured directly and cannot be calculated to the desired accuracy, $B^{2}$ is evaluated using the experimental value of $k_{\infty}$ from Eq. (A.12) via the relation in Eq. (A.11). It was necessary to iterate on the buckling value from Eq. (A.11) in calculations of lattice parameters defined in Eq. (A.5) through (A.8). These methods eliminate errors in the buckling due to uncertainties in the fuel block loading, heterogeneous geometry, and limitations of calculational methods.

The HTLTR experiments were designed to make use of the tremendous power of Eq. (A.12) to determine $k_{\infty}-1$ and therefore $k_{\infty}$ to a high degree of accuracy. In all five of the HTGR lattice experiments, the calculated terms contribute less than $10 \%$ to $k_{\infty}-1$. Therefore if the sum of these terms were estimated within $10 \%$, they contributed less than $1 \%$ error in $k_{\infty}-1$. Reaction rate ratios were measured within a $2 \%$ uncertainty, and the uncertainties in the neutron spectrum mismatch for $k_{\infty}$ near unity 1 imit the minimum error to about 0.001 . So, the overall uncertainty in $k_{\infty}-1$ was about $4 \%$. For a typical $k_{\infty}$ of 1.08 the overall uncertainty is only 0.003 , or $0.3 \%$. No other method utilizing only a small portion of a critical mass approaches this range of accuracy.

Another advantage of the formulation in Eq. (A.12) is that only thermal absorption rates in the central cell constituents must be evaluated from foil activation measurements to determine $k_{\infty}$. The uncertainties involved in evaluating epithermal resonance absorption rates in the fuel and epithermal capture-to-fission ratios in fissionable materials were eliminated. In addition it should be noted that except for the errors in measuring reactivity perturbations, $\Delta \rho$, all other uncertainties in $k_{\infty}-1$ were systematic with changes in temperature. Therefore the uncertainty in $\left[k_{\infty}\left(T_{2}\right)-k_{\infty}\left(T_{1}\right)\right]$ was also about $4 \%$, and in fact was less than the overall uncertainty in $k_{\infty}$.

The formulation in Eq. (A.12) has general limitations which were evaluated to substantiate its applicability to the particular HTGR lattice situations. For HTGR and other thermal spectrum test lattices, the thermal and epithermal neutron leakage correction terms are an order of magnitude smaller than the experimentally evaluated term which is normalized by thermal 
neutron absorption rates. If the test lattice is nonthermal, $p \rightarrow 0$ and $\eta_{1} f_{1} \rightarrow k_{\infty}$, the epithermal leakage correction becomes prohibitively large and a different formulation is required.

The evaluation of $k_{\infty}$ in the fundamental mode has the advantage of unique fluxes regardless of the multi-group neutron energy structure used. If there is insufficient test lattice surrounding the center cell to establish these unique fluxes within the epithermal and thermal groups, or if a dissimilar test lattice surrounds the center cel1, the two-group mismatch corrections given in Eq. (A.12) would be inappropriate. For those cases, a more general multi-group equation must be used to evaluate $k_{\infty}$, with some sacrifice in accuracy. It is not necessary to mockup the entire HTLTR to calculate $k_{\infty}(T)$ values for comparison to the experimental values. Only a bare critical assembly of the test material must be mocked up to calculate $k_{\infty}$ in the fundamental mode at each measurement temperature. However, it was necessary to mockup the entire HTLTR to calculate the small correction terms for neutron flux and adjoint spectral mismatch in the central cell void. The details on the reactor loadings that were necessary to make these entire HTLTR calculations are given in the original PNL reports for each experiment (see references $7,9,11,13,14$, and 21 ). 
APPENDIX B

EXPERIMENTAL PROCEDURES

CO MOT GERORIIA
THS PAGE 


\section{APPENDIX B}

\section{EXPERIMENTAL PROCEDURES}

Detailed descriptions of the experimental procedures used in the HTLTR for each of the five HTGR lattice test cores are provided in the original PNL reports for those experiments (see references $7,9,11,13,14$, and 21). A summary description of those procedures is provided here for completeness.

\section{TEST LATTICE CONFIGURATION}

Each HTGR test lattice in the HTLTR was arranged similar to that shown in Figure $\mathrm{B} .1$ for the $\mathrm{ThO}_{2}-\mathrm{PuO}_{2}$ HTGR test lattice. the HTGR fuel blocks were loaded into the center of the HTLTR in an $8 \times 8$ array. The outer two rows of blocks are 4-ft in length; the inner $4 \times 4$ array of HTGR blocks are $6-\mathrm{ft}$ in length. External to the test lattice, the HTLTR was loaded with short end drivers adjacent to the ends of the test lattice and, radially, with driver fuel buffer fuel, and temperature compensating shims (22) as appropriate to provide sufficient reactivity for reactor operations and to adjust the neutron spectrum incident on the test lattice.

\section{NEUTRON SPECTRUM MATCHING}

The required reactivity measurements in the central void of the HTLTR were made with a reactor loading where the neutron spectrum in the vicinity of the central test cell was nearly the same as in a bare critical array of the test lattice.

To determine the reactor configuration external to the test lattice likely to give a good flux match in the vicinity of the central test cell, calculations were made using the two-dimensional diffusion theory code $2 \mathrm{DB}(23)$ and a two-energy-group model of the HTLTR in $R-Z$ geometry. The lattice spectrum was matched when the thermal-to-epithermal flux ratio in the region adjacent to the central cell is the same as in the central cell. Spatial variations of the neutron spectrum were measured throughout the HTLTR using bare and cadmium-covered gold foils. The neutron spectrum index (gold 


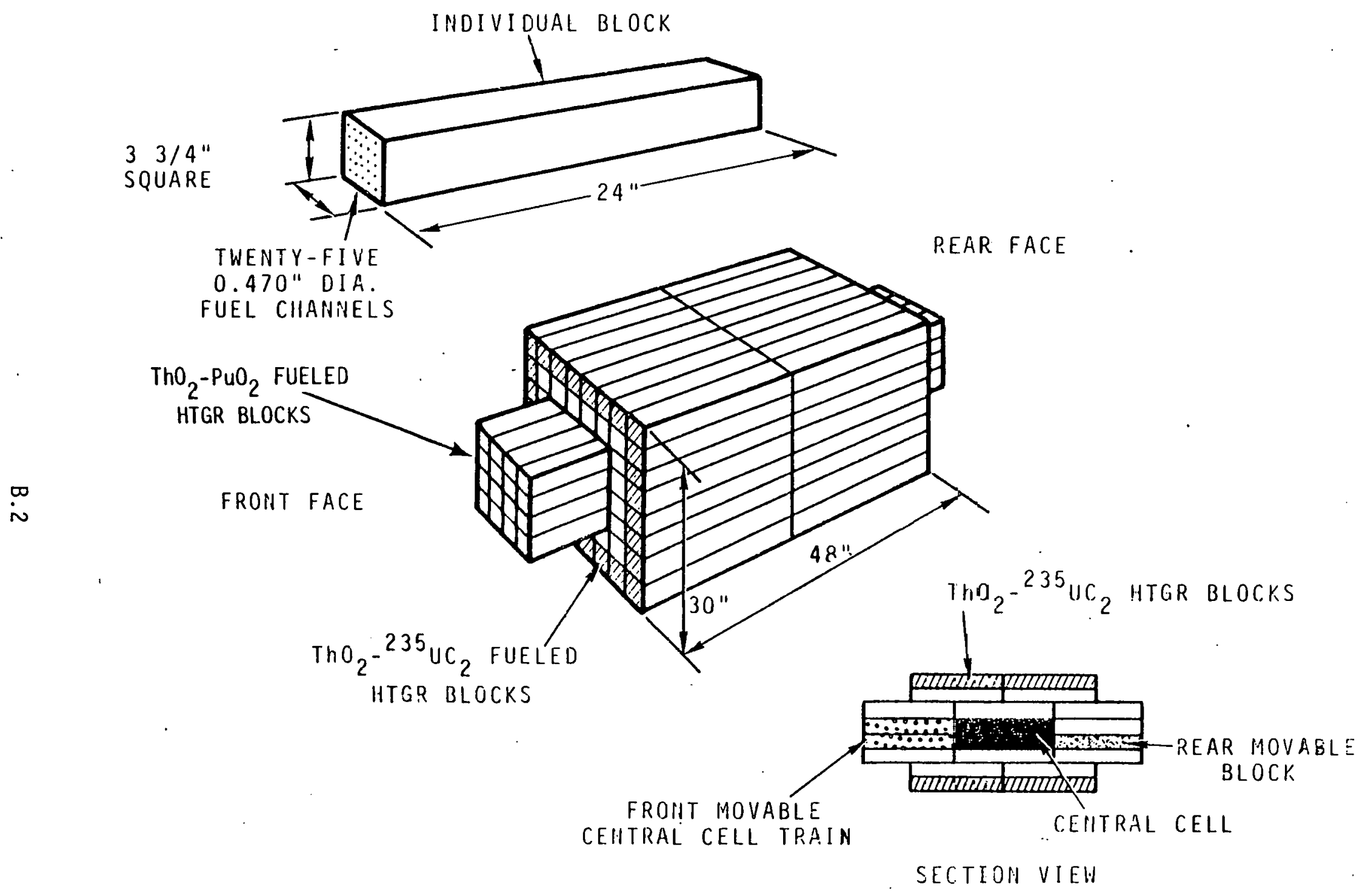

FIGURE B.1. $\mathrm{ThO}_{2}-\mathrm{PuO}_{2}$ HTGR Test Lattice (Central Region of HTLTR) 
cadmium ratio-1) is directly proportional to the thermal-to-epithermal flux ratio. An example of the comparison of measured and calculated (gold cadmium ratio-1) values in the radial direction, shown in Figure B.2, and in the axial direction, shown in Figure B.3, indicate excellent agreement. Similar good agreement was obtained for the other HTGR test lattices. These results provide validation of the 2DB calculations for the entire HTLTR that were used to provide reasonable estimates of two-group flux mismatch corrections for the $k_{\infty}$ measurements. In addition, to minimize axial streaming, the neutron flux level in the HTLTR was flattened in the axial direction as illustrated in Figure B.4. To change the neutron flux level and spectrum, driver fuel and gadolinium shims were adjusted in the radial and axial regions of the HTLTR surrounding the test lattice.

\section{Measurement of Reaction Rates}

The measurement of relative thermal reaction rates in the actual cell and copper absorber was carried out at room temperature using foils. These foils were normalized to foils placed on a rotator at a location near the edge of the HTLTR. The rotator ensures that each type of foil sees an identical flux.

The reaction rate in the copper poison was measured by placing the poison strips in the cavity left when the central cell was removed and irradiating the material. Foils were punched from selected locations in the strips and the copper activity determined, to obtain the integral of absorptions in the poison strips.

The cell reaction rate was measured using 0.005 -inch copper foils to evaluate $1 / v$ absorptions and fuel foils to evaluate fuel absorption. The copper foils were placed axially and radially between the central cell blocks to allow an integral of the flux over the cell to be calculated. A special fuel block, shown in Figure B.5, containing the same HTGR fuel mixture as the central cell blocks was used to hold foils for the reaction rate measurements. This block had the fuel in two channels contained in removable aluminum cylinders, three in each channel, between which foils could be inserted. Special foils were fabricated to fit in the fuel channels. Foils made of copper and foils containing a mixture of coated fissile fuel 


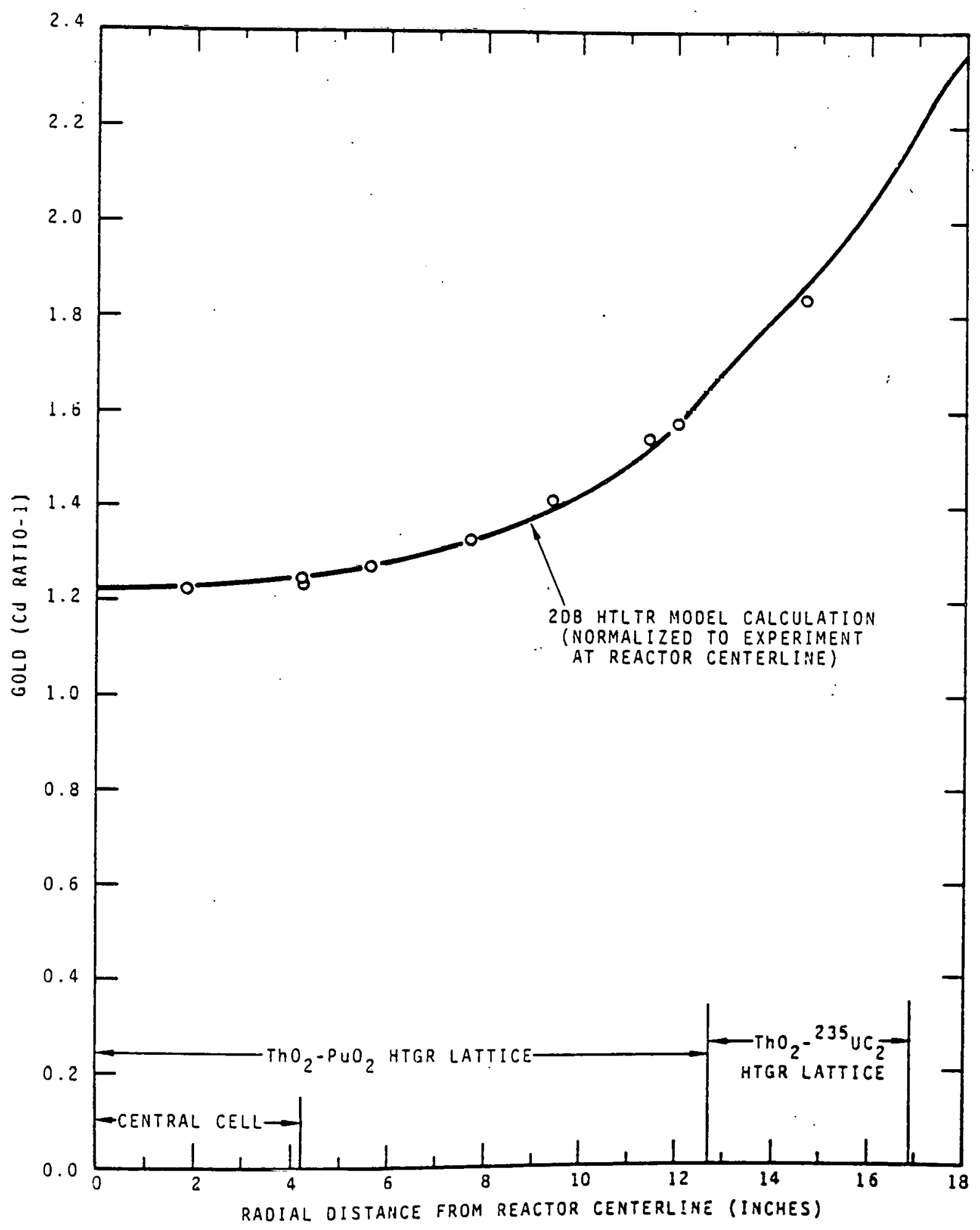

FIGURE B.2. Comparison of Measured and Calculated (Gold Cadmium Ratio -1) as a Function of Radial Distance from the Reactor Centerline 


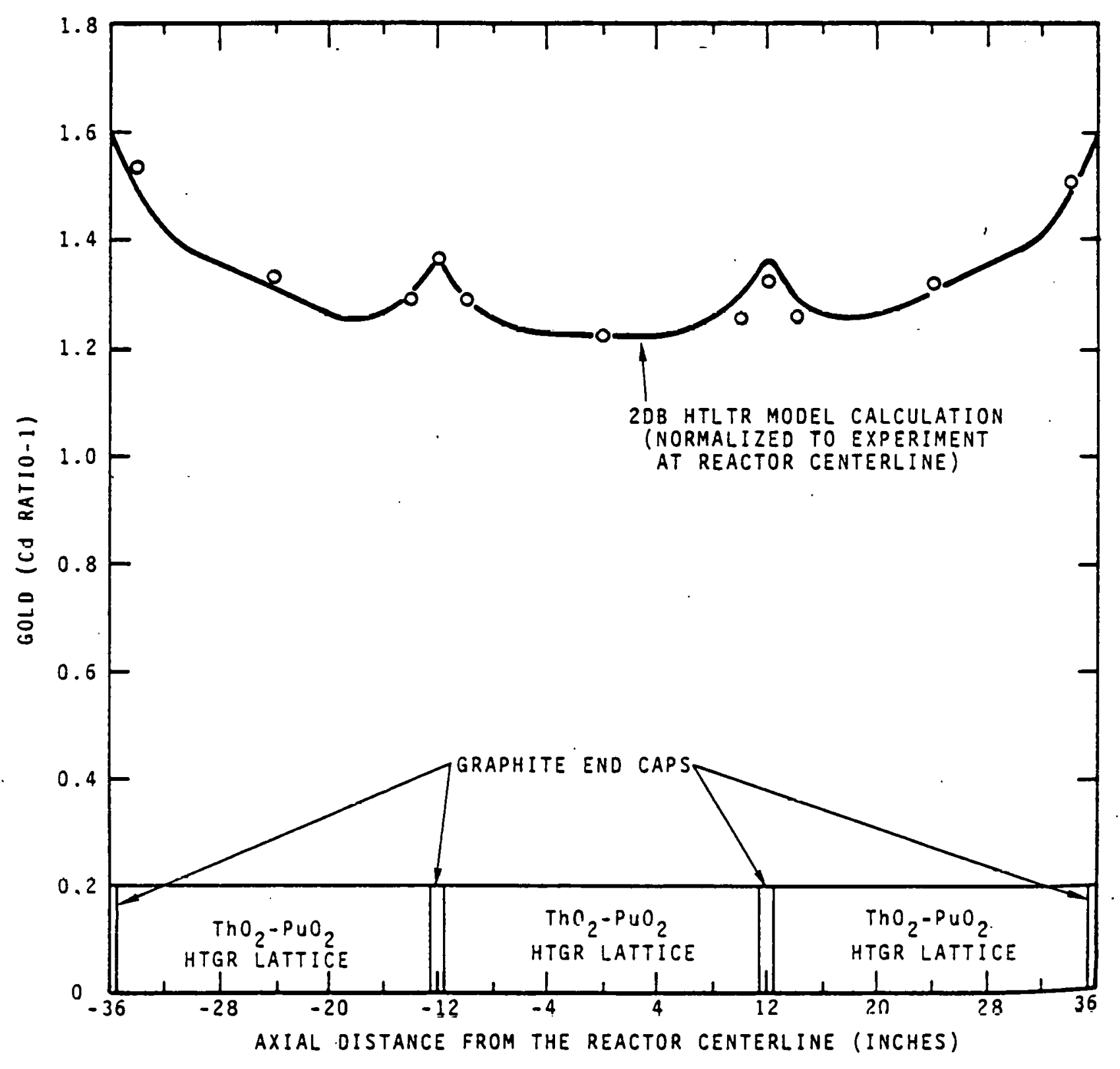

FIGURE B.3. Comparison of Measured and Calculated (Gold Cadmium Ratio -1) as a Function of Axial Distance from the Reactor Centerline

microspheres, $\mathrm{ThO}_{2}$ particles, and graphite identical to the test lattice fuel were used. These fuel foils were used to evaluate the relative absorption rates in fissile fuel and thorium.

In order to evaluate relative thermal absorptions, both bare and cadmium-covered (0.040-inch thick cadmium) foils were irradiated. The 


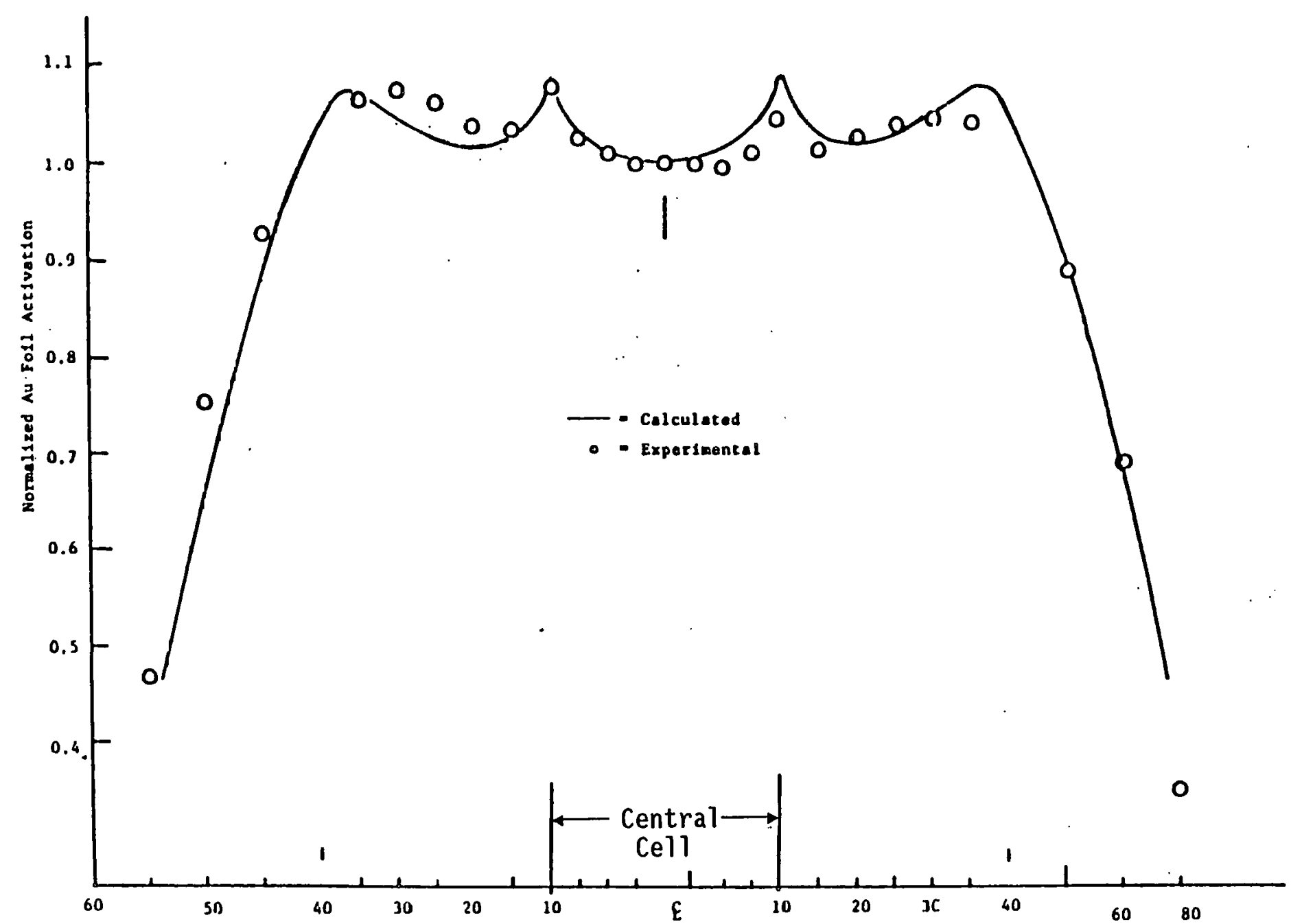

FIGURE B.4. Bare Gold Axial Traverse 


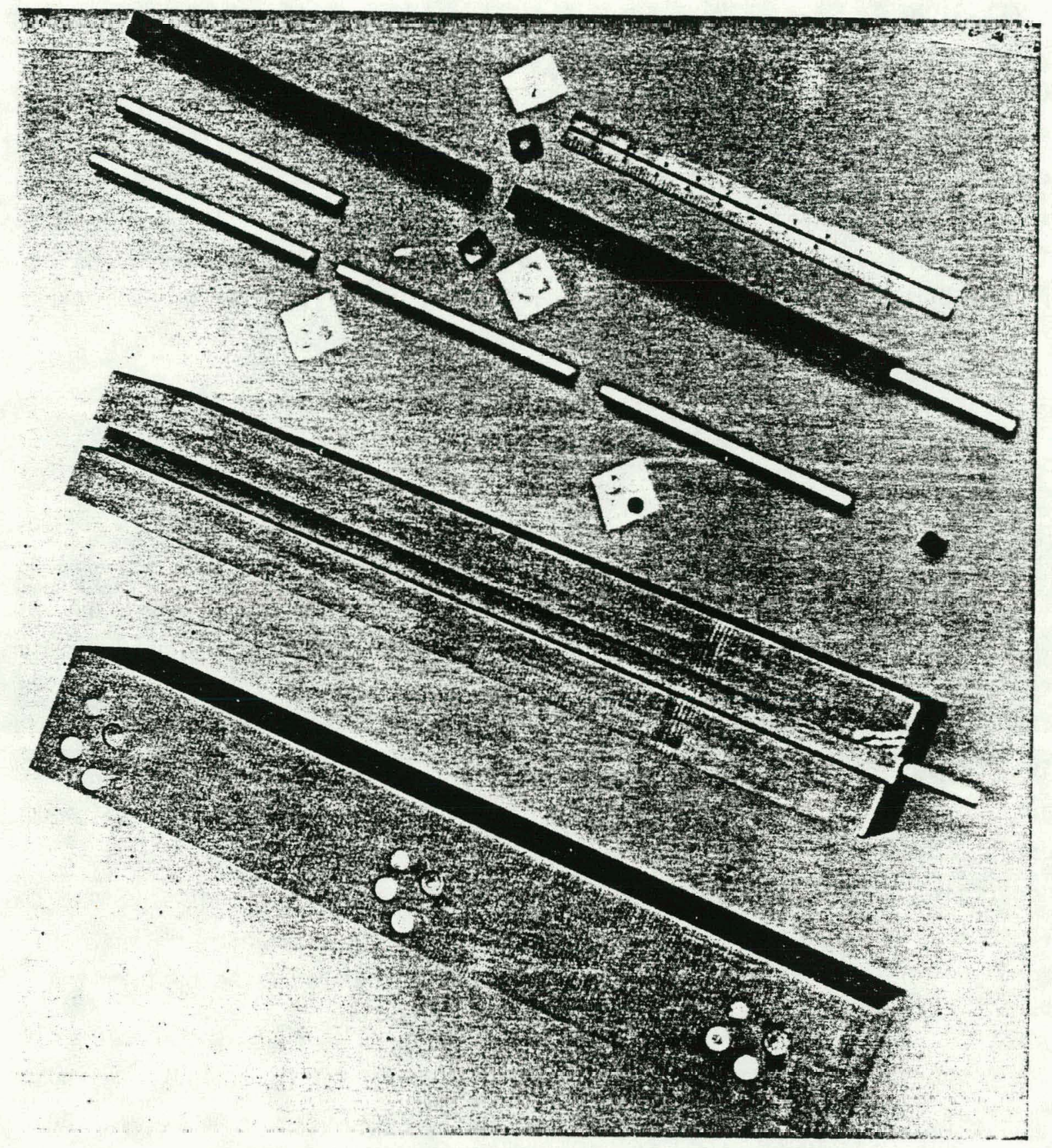

FIGURE B.5. Special HTGR Fuel Block Used in Foil Irradiations

measured relative reaction rates were then corrected for the perturbations caused by the aluminum, the foils, and cadmium covers. (20) These corrections were calculated using the two-dimensional transport theory code DOTSN. (12) The corrections to the bare activity were smal1 (about $0.5 \%$ or 1 ess). The

\section{B.7}


corrections for the cadmium cover perturbations were larger, however. These perturbations arise from depression of the epithermal flux in the vicinity due to thermal absorption in the cadmium, epithermal absorption in the cadmium, and due to production of thermal neutrons by scattering inside the cadmium cover. The DOTSN calculation provides the thermal and epithermal flux inside the cadmium cover relative to the unperturbed flux far from the foil. For example, the thermal and epithermal activation rates in the $\mathrm{PuO}_{2}-\mathrm{ThO}_{2}$ HTGR fuel were evaluated, using the DOTSN results by the relations:

$$
\begin{aligned}
& A_{\text {Thermal }}=1.004 \mathrm{~A}^{\text {bare }}-1.036 \mathrm{~A}^{\mathrm{Cd}} \\
& \mathrm{A}_{\text {Epithermal }}=1.034 \mathrm{~A}^{\mathrm{Cd}}-0.0006 \mathrm{~A}^{\text {bare }} .
\end{aligned}
$$

It was also necessary to correct for epithermal absorption in the monitor foils located near the edge of the HTLTR. Measured copper and gold cadmium ratios at the monitor location were used to evaluate these corrections. These corrections decreased the measured monitor foil activities by about $7 \%$ in thorium, $1 \%$ in copper, and $0.4 \%$ in plutonium. The relative thermal activation rates (in the central cell fuel to the monitor location) for the corrected thorium activation measurements agreed within experimental uncertainties with the corrected copper activation measurements. Since the thermal absorption cross sections of both thorium and copper are $1 / v$, this agreement between relative thermal activation rates tends to confirm the corrections made for epithermal absorption in the monitor foils.

Thermal cross sections at the monitor location were evaluated using a spectrum from a THERMOS(12) calculation of the HTLTR. The cross sections of the materials in the fissile fuel microspheres and the $\mathrm{ThO}_{2}$ particles at the monitor location were calculated using an averaging routine CROSAV(12) which uses a collision probability routine together with the THERMOS fluxes and cross sections from the THERMOS BNW master 1ibrary to calculate effective cross sections in the particle. 
Measurement of Reactivities

Reactivity measurements were made by placing a sample in the void and measuring the change in reactor asymptotic period. The change in reactivity was then calculated using the inhour equation. A correction for the reactivity of the nitrogen in the void was calculated from the worth of copper in the void. Using the $\mathrm{PuO}_{2}-\mathrm{ThO}_{2}$ HTGR lattice as an example, this correction for the 7-1/2 × 7-1/2 $\times 24-$ inch void and the corrected reactivity worths for the various central cells, copper, and graphite, are summarized in Table B.l. The central cell worth, corrected for graphite end caps, is included in Table B.1. These reactivity worths include the $\mathrm{N}_{2}$ in the pores of the graphite.

TABLE B.1. Reactivity Worth Measurements

\begin{tabular}{|c|c|c|c|c|c|}
\hline & $\begin{array}{l}20^{\circ} \mathrm{C} \\
\mathrm{C} \\
\end{array}$ & $\begin{array}{r}300^{\circ} \mathrm{C} \\
\mathrm{C} \\
\end{array}$ & $\begin{array}{c}500^{\circ} \mathrm{C} \\
\mathrm{C} \\
\end{array}$ & $\begin{array}{c}750^{\circ} \mathrm{C}, \\
\mathrm{C}\end{array}$ & $\begin{array}{c}1000^{\circ} \mathrm{C}, \\
\mathrm{C}\end{array}$ \\
\hline $\mathrm{N}_{2}$ Correction & -0.96 & -0.49 & -0.32 & -0.22 & -0.16 \\
\hline $\begin{array}{l}\text { Standard } 4 \text { Block } \\
\text { Central Cell (W/End Caps) } \\
\text { (Without End Caps) }\end{array}$ & $\begin{array}{l}+13.57 \\
+11.90\end{array}$ & $\begin{array}{l}+11.98 \\
+10.10\end{array}$ & $\begin{array}{r}+11.33 \\
+9.27\end{array}$ & $\begin{array}{l}+9.91 \\
+7.74\end{array}$ & $\begin{array}{l}+7.29 \\
+5.05\end{array}$ \\
\hline $\begin{array}{l}\text { Copper in Void } \\
(209.898 \mathrm{~g})\end{array}$ & -3.64 & -3.40 & -3.15 & -2.90 & -2.75 \\
\hline $\begin{array}{l}\text { Graphite Carrier } \\
(2038 \mathrm{~g})\end{array}$ & +2.17 & +2.44 & +2.67 & +2.83 & +2.89 \\
\hline
\end{tabular}

Additional measurements were made at room temperature in air. These measurements included a measurement of the copper worth on the carrier versus the copper worth in the void and the worth of an amount of graphite equivalent to the end cap region on the central cell. The effect of the carrier graphite was found to increase the worth per gram of copper on the carrier, relative to copper placed alone in the void, by $(3.3 \pm 0.8) \%$. This normalization was used to evaluate copper worths in the void at elevated temperatures from the measured copper worths on the carrier. The worth per gram of the dummy end cap graphite was $(5 \pm 2) \%$ larger than the worth per gram of the 
graphite carrier. Similarly, this normalization was used to evaluate the end cap worth at elevated temperatures from the measured graphite carrier worth.

The HTGR experiments utilized the remote sample changer for the HTLTR, shown in Figure 7 . This device allowed samples to be preheated before insertion in the reactor and thus enables temperature transients during sample changes to be minimized. This resulted in a time saving during reactivity measurements and an improvement in accuracy. Errors have not been included in Table B.1, but typical errors might be $\pm 0.02 \mathrm{c}$ at room temperature, $\pm 0.04 \mathrm{c}$ at $300^{\circ} \mathrm{C}, 500^{\circ} \mathrm{C}$, and $750^{\circ} \mathrm{C}$, and $\pm 0.07 \mathrm{C}$ at $1000^{\circ} \mathrm{C}$. These errors are estimated from the consistency of the data and represent approximately nne standard deviation. A second advantage of the remote sample changer was the elimination of the extension effect which created an uncertainty in earlier experiments. $(7,21)$ 


\section{DISTRIBUTION}

No. of

Copies

OFFSITE

12 DOE/Office of Scientific and Technical Information

U.S. Department of Energy F-434/GTN

Advanced Reactor Programs, NE-45

Washington, D.C. 20545

Attn: A. C. Millunzi

U.S. Department of Energy

Office of New Production Reactors 613-104/FOR

Washington, D.C. 20585

Attn: J. D. Nulton

EG\&G Idaho, Inc.

P.0. Box 1625

Idaho Falls, ID 83415

Attn: R. K. McCardell

7 Los Alamos National Laboratory

P.0. Box 1663 , MS K575

Los Alamos, NM 87545

Attn: G. E. Hansen

J. E. Hanson

W. L. Kirchner

J. J. Malanify

R. G. Palmer

W. H. Reed

J. L. Sapir
No. of

Copies

ONSITE

DOE Richland Operations Office

J. M. Hennig

5 Westinghouse Hanford Company

D. S. Dutt

M. K. Korenko

L. A. Lawrence

R. P. Omberg

R. W. Powell

18 Pacific Northwest Laboratory

W. J. Apley

L. R. Dodd

G. J. Konzek

D. F. Newman (5)

A. W. Prichard

B. D. Shipp

R. I. Smith

H. H. Van Tuyl Publishing Coordination Technical Report Files (5)

\section{CO MOT BMRROFHM THS PAGE}

